\title{
Typology of fish nurseries in shallow Mediterranean coastal zones: all habitats matter
}

Adrien Cheminée ( $\square$ adrien.cheminee@septentrion-env.com )

Septentrion Environnement

\section{Laurence Le Direach}

GIS Posidonie, OSU Institut Pytheas

\section{Elodie Rouanet}

GIS Posidonie, OSU Institut Pytheas

\section{Patrick Astruch}

GIS Posidonie, OSU Institut Pytheas

\section{Adrien Goujard}

GIS Posidonie, OSU Institut Pytheas

\section{Aurélie Blanfuné}

Mediterranean Institute of Oceanography

\section{Denis Bonhomme}

GIS Posidonie, OSU Institut Pytheas

\section{Laureline Chassaing}

GIS Posidonie, OSU Institut Pytheas

\section{Jean-Yves Jouvenel}

P2A Développement

\section{Sandrine Ruitton}

Mediterranean Institute of Oceanography

Thierry Thibaut

Mediterranean Institute of Oceanography

Mireille Harmelin-Vivien

Mediterranean Institute of Oceanography

\section{Research Article}

Keywords: juvenile fish, nursery, abundance, rocky substrates, soft bottoms, seagrass beds

Posted Date: December 10th, 2020

DOI: https://doi.org/10.21203/rs.3.rs-118728/v1 
License: (c) (i) This work is licensed under a Creative Commons Attribution 4.0 International License. Read Full License

Version of Record: A version of this preprint was published at Scientific Reports on July 16th, 2021. See the published version at https://doi.org/10.1038/s41598-021-93557-2. 
1 Typology of fish nurseries in shallow Mediterranean coastal zones: all habitats matter.

4 Adrien Cheminée ${ }^{1,2^{*}}$, Laurence Le Direach ${ }^{3}$, Elodie Rouanet $^{3}$, Patrick Astruch $^{3}$, Adrien

5 Goujard $^{3,5}$, Aurélie Blanfuné ${ }^{4}$, Denis Bonhomme ${ }^{3}$, Laureline Chassaing ${ }^{3}$, Jean$^{-Y_{v}}$ Jes Jouvenel $^{6}$,

6 Sandrine Ruitton ${ }^{4}$, Thierry Thibaut ${ }^{4}$, Mireille Harmelin-Vivien ${ }^{4}$

7

$8{ }^{1}$ Aix Marseille Université, Faculté des Sciences, 163 Avenue de Luminy, Case 901, 13288

$9 \quad$ Marseille, France

102 Septentrion Environnement, Lycée des Calanques, 89 Traverse Parangon, 13008 Marseille,

11 France

$12{ }^{3}$ GIS Posidonie, OSU Institut Pytheas, Oceanomed, case 901, Campus de Luminy, 13288

13 Marseille cedex 9, France

$14{ }^{4}$ Aix Marseille Univ., Université de Toulon, CNRS, IRD, MIO UM 110, 13288, Marseille,

15 France

165137 chemin de Morgiou, 13009 Marseille, France

$17{ }^{6}$ P2A Développement, 87 av. F. de Lesseps, impasse Algrin, 34110 Frontignan, France

18

$19 *$ Corresponding author: adrien.cheminee@septentrion-env.com

20

21 Key words: juvenile fish, nursery, abundance, rocky substrates, soft bottoms, seagrass beds 22 


\section{Abstract}

25 Coastal zones are ecosystems of high economic value but exposed to numerous disturbances, while they represent nurseries for many fish species, raising the issue of the preservation of their

27 functions and services. In this context, the juvenile fish assemblages of all types of habitats present in shallow coastal zones were studied on the south-east coast of France using underwater

29 visual censuses. The abiotic and biotic descriptors of the 14 habitat types individualized did not vary with time, except for a higher cover percentage and canopy height of macrophytes in the warm period, which increased the three-dimensional structure of some habitats. The taxonomic

32 composition and density of juvenile fish assemblages were analyzed using both multivariate and univariate descriptors, after grouping the 57 fish species recorded into 41 well-individualized taxa. Juvenile fishes were recorded in all habitat types, with higher mean species richness and abundance during the warm than the cold period. The richest habitats in terms of both species richness and abundance were the natural rocky substrates and the interfaces between Posidonia beds and the other habitats. Although juvenile fish assemblages differed among habitat types and between periods, the most abundant fish species (Atherina sp., Sarpa salpa, Gobiidae, Symphodus spp., Pagellus spp. and several Diplodus species) colonized different habitat types (from 7 to 14) during their juvenile life. This study provided evidence of the role of all types of

41 shallow coastal habitats as fish nurseries and their varying pattern of occupation in space and 42 time by the different juvenile stages. It highlighted the importance of the mosaic of habitats and 43 interfaces for the complete development of all juvenile life stages of fishes, and for the 44 preservation of a high diversity of coastal fish assemblages and fisheries resources in the 45 Mediterranean Sea. 
49 Coastal areas have long been known as high commercial value areas ${ }^{1,2}$ but also as the zones most 50 impacted by anthropogenic disturbances ${ }^{3,4}$, including habitat destruction ${ }^{5}$, chemical pollution ${ }^{6,7}$, 51 artisanal and recreational fishing ${ }^{8,9}$, and more recently anthropogenic noise pollution ${ }^{10}$. However, 52 coastal zones also represent nursery sites for numerous fishes, including commercial species ${ }^{11-13}$.

53 Most benthic and demersal fish species present a bipartite life cycle with a dispersive pelagic 54 larval phase and a more sedentary benthic adult phase ${ }^{14}$. Depending on the species-specific 55 planktonic larval phase duration $(\mathrm{PLD})^{15}$, reproduction products may be dispersed on a more or 56 less extensive stretch of coastline, ranging from a few hundred meters to hundreds of

57 kilometers ${ }^{16-18}$. When competent, the surviving larvae metamorphose into juveniles and settle in 58 specific habitats (settlement phase) where they grow for a few months, before being recruited 59 into adult populations (recruitment phase) generally in deeper and more diverse habitats, as 60 juveniles and adults often occupy different habitat types ${ }^{11,19,20}$. As the replenishment of local 61 adult fish populations depends on the success of their larval and juvenile phases, juvenile 62 survival in nursery habitats means that they are of paramount importance with regard to the fish 63 life cycle, stock conservation and fisheries exploitation ${ }^{21-24}$. Settlement in nurseries may occur at 64 different times of the year according to species ${ }^{25,26}$. Moreover, although some alternatives may 65 exist, the settlement-recruitment process usually follows similar patterns: during settlement, one main or several cohorts of settlers may occur, resulting in a uni- or pluri-modal settlement peak.

67 This peak may be quantified as the density of new settlers per unit area of habitat and is referred 68 to as "settlement intensity" or "settlement success"20,27. The settlement peak is then followed by 69 a period where juveniles grow inside nursery habitats, and during which they may display 70 ontogenic habitat changes, switching between various nursery habitats as they grow and require 
71 new resources ${ }^{19}$. Ultimately, surviving juveniles (recruits) may join adult populations and

72 habitats (i.e. recruitment). The quantity of surviving juveniles inside nurseries after an arbitrary

73 period of time following settlement has been used as a measure of "recruitment level"27. Beck

74 and collaborators ${ }^{11,28}$ describe the "nursery value" of a given habitat as a more comprehensive

75 view of these descriptors: the nursery value of a given habitat is the quantity of new individuals

76 produced per unit area and provided to adult populations as an outcome of the combination of

77 four components: the initial number of settlers provided to a nursery, their growth and survival,

78 and their capacity to join the adult population (functional and structural connectivities) (but see

79 other works for alternative points of views ${ }^{13,24}$ ).

80 Numerous studies have been undertaken on the role of particular shallow coastal habitats as fish

81 nursery sites in the Mediterranean Sea. One approach was to focus on one type of habitat, such

82 as coastal lagoons ${ }^{29,30}$, soft bottoms ${ }^{31,32}$, Cymodocea nodosa meadows ${ }^{33-36}$, Posidonia oceanica

83 beds $^{37-41}$, shallow rocky reefs more or less colonized by macrophytes assemblages ${ }^{42-49}$ and

84 shallow heterogeneous rocky substrates ${ }^{50,51}$. Another approach was to focus on specific fish

85 species such as the gilthead seabream Sparus aurata ${ }^{52}$, sparids of the genus Diplodus ${ }^{25,53-57}$,

86 flatfishes such as Solea solea ${ }^{58,59}$, the dusky grouper ${ }^{60-63}$, or labrid species ${ }^{64-66}$.

87 While a few studies were focused on multiple habitats ${ }^{26,67-69}$, no study has been yet

88 systematically carried out on all habitat types encountered along the coast without any a priori

89 assumption regarding their potential role as nurseries for fishes. The present study was thus

90 designed to explore the potential contribution of all shallow $(<6 \mathrm{~m})$ coastal habitats and their

91 interfaces (i.e. ecotones) as fish nurseries on the coasts of Provence (France, NW

92 Mediterranean), whatever the type and intensity of human pressures. The aims of the present

93 study were to 1) define the environmental characteristics of the habitat types present in shallow 
94 coastal habitats and their main temporal variations, 2) characterize the juvenile fish assemblages

95 associated with the different habitats and relate or not their seasonal variations to environmental

96 changes in habitat structure, and 3) determine the potential of the different habitat types as

97 nurseries for juvenile Mediterranean coastal fishes.

98

99 Material and methods

100

Ethics statement

101 The observational protocol was submitted to the regional authority 'Direction interrégionnale de

102 la mer Méditerranée' (the French administration in charge of Maritime Affairs), which did not

103 require a special permit since no extractive sampling or animal manipulations were performed

104 (only visual censuses in natural habitats), since the study did not involve endangered or protected 105 species and since the surveyed locations were not privately owned.

\section{Sites and sampling methods}

107 Juvenile fish were monitored by underwater visual censuses (UVC) ${ }^{70}$ in a wide variety of 108 habitats from 0 to $6 \mathrm{~m}$ depth at 42 stations randomly spread along a $100 \mathrm{~km}$ long stretch of the 109 Provence coastline (Fig. 1). A random sampling design was adopted to encompass the natural 110 characteristics and spatial variability of shallow coastal habitats during the warm (June-July

111 2014) and cold (April 2015) seasons (Table 1), as fish settlement shows wide seasonal

112 variation $^{26,42,71}$. A total of $2101 \mathrm{UVC}$ samples were undertaken. Each sample was a priori

113 attributed to one of 14 habitat types defined according to the main types of substrates present in

114 shallow sublittoral Mediterranean coastal areas, i.e. natural and artificial rocky substrates, soft

115 bottoms and seagrass beds, along with their main ecotones (hereafter named interfaces) (Table

116 1), according to previous studies on juvenile fish settlement in the Mediterranean Sea ${ }^{25,36,37,45}$. 
117 Fishes were recorded on $2 \times 1 \mathrm{~m}\left(2 \mathrm{~m}^{2}\right)$ quadrates on natural rocky substrates (RS), $5 \times 2 \mathrm{~m}$ $118\left(10 \mathrm{~m}^{2}\right)$ belt transects in C. nodosa meadows (CY and POCY) and $10 \mathrm{x} 1 \mathrm{~m}\left(10 \mathrm{~m}^{2}\right)$ transects in 119 all other habitats, including $P$. oceanica beds, adapted according to the spatial extent, variability 120 and heterogeneity of habitat characteristics ${ }^{72,73}$. All fishes smaller than $10 \mathrm{~cm}$ in total length (TL) 121 were identified at species or genus level, and their abundance and size (TL, to the nearest $\mathrm{cm}$ 122 between $4-10 \mathrm{~cm}$, to $0.5 \mathrm{~cm}$ under $4 \mathrm{~cm}$ TL) were recorded. In addition, a set of habitat 123 descriptors were recorded in order to verify a posteriori that the sampling units (visually 124 selected) were appropriately classified into meaningful and objectively-defined habitat types. 125 After each fish count, a set of 26 habitat descriptors were recorded in quadrates or when 126 swimming back along transects in order to describe precisely the abiotic and biotic habitat 127 characteristics: depth (m), slope (integer scale from 1 to 6), percent coverage of substrate types 128 (6 types), rugosity classes (4 classes), vegetal types (3 types of seagrasses and 5 types of other 129 macrophytes), and height $(\mathrm{cm})$ of the canopy ${ }^{26,72,74}$ (Table 2). For convenience we used the term 130 Cystoseira forest although the genus has been recently divided into three ${ }^{75}$. Whatever the genus 131 actually used, Carpodesmia, Treptacantha or Cystoseira, all species display erect arborescent 132 thalli and functionally form a forest ${ }^{76,77}$.

133 For statistical analyses, only the juvenile individuals of the species recorded were considered 134 following literature information, as the size limit between juvenile and adult stages varies among 135 species depending on their maximum size and biology ${ }^{57,72,74}$. 


\section{Data analysis}

140 Our sampling effort produced a data-frame containing 2101 lines (one per sample) with data

141 ordered by columns for each fish (taxa: densities per species and per size-class) and habitat

142 descriptors (i.e. metrics describing habitat characteristics).

\section{$144 \quad$ Habitat descriptor analysis}

145 A first set of analyses was performed on a subset of this data-frame, displaying only habitat

146 descriptors for each sample. Multivariate descriptors of habitat were previously standardized and

147 the Euclidean distance was used as a measure of dissimilarity due to the different nature and

148 variation range of the descriptors used $^{78}$. Ordination methods were applied to the distance matrix

149 calculated from this data-frame in order to verify whether samples would be grouped by clusters

150 in accordance with their a priori habitat types. Since a first visual interpretation of ordination bi-

151 plot indicated that samples were in effect grouped by habitat types (see results), we calculated a

152 new matrix of distance between centroids for the grouping factor "Habitat-Station-Period",

153 which enabled us to display a clearer visual representation using ordination. To represent

154 dissimilarities between samples of habitat descriptor assemblages, we performed a Principal

155 Coordinate Analysis (PCoA) ordinations plot of centroids of descriptor samples of the dummy

156 factor combining station, habitat type and period ${ }^{79,80}$. Arrows were superimposed onto PCoA bi-

157 plots to represent the Spearman's rank correlations between biplot axes and habitat descriptors ${ }^{78}$.

158 Complementarily, in order to test whether samples would indeed significantly differ in terms of 159 metrics assemblages as a function of their habitat types, we applied to this last distance matrix a

160 PERMutational multivariate ANalysis Of VAriance (PERMANOVA) using the algorithm

161 developed by Anderson et al. ${ }^{80}$. The PERMANOVA model included two factors: (i) "Habitat" 
162 was fixed and included 14 levels (Table 1) and (ii) "Period" was fixed and included two levels

163 (warm and cold).

165 Juvenile fish assemblage analysis

166 We applied the same model (Habitat $\mathrm{x}$ Period) in order to test the effect of both factors on the

167 descriptors of the juvenile fish assemblages. We used both univariate (taxa richness, total

168 assemblage density) and multivariate (composition and relative densities of taxa) descriptors as

169 response variables. In order to represent dissimilarities between samples in terms of juvenile fish

170 multivariate assemblages, according to habitats and period, we performed Principal Coordinate

171 Analysis (PCoA) ordinations plot of samples. Arrows were superimposed onto PCoA bi-plots to

172 represent the Spearman's rank correlations between bi-plot axes and taxa densities ${ }^{78,79}$.

173 Complementarily, for each assemblage descriptor (i.e. multivariate taxa densities, richness, total

174 densities), in order to test whether samples would indeed significantly differ in terms of

175 assemblage descriptors as a function of their habitat types and/or period, we applied to each

176 respective distance matrix a PERMutational uni/multivariate ANalysis Of VAriance

177 (PERMANOVA) using the algorithm developed by Anderson et al. ${ }^{80}$. The PERMANOVA

178 model included two factors: (i) "Habitat" was fixed and included 14 levels (Table 1) and (ii)

179 "Period" was fixed and included two levels (warm and cold). For univariate descriptors (richness

180 and total densities), we used the Euclidian distance while for the multivariate assemblage

181 descriptor (relative taxa densities), we used the Modified Gower distance measure as suggested

182 by Anderson et al. ${ }^{80}$. Additionally, for a set of 6 Sparidae taxa whose juvenile habitats have been

183 particularly described in the past ${ }^{25}$, mean individual sizes (TL, cm) were compared between 
184 treatments using t-tests (Diplodus annularis, D. vulgaris, D. sargus, Oblada melanura, Pagellus 185 spp., Sarpa salpa).

186 Sums of squares (SS) for all PERMANOVA designs were performed as a fully partial analysis

187 (type III). P-values were obtained by 999 permutations of residuals under a reduced model.

188 Monte Carlo P-values were considered when there were not enough possible permutations

$189(<200)$. Terms were pooled as suggested by Anderson et al. ${ }^{80}$. Due to the intrinsic variability of

190 ecological data, tests were considered significant for $\mathrm{P}$-values $<0.1$. Multivariate exploratory

191 analyses and both multivariate and univariate inferential tests were performed using the PRIMER

1926 software and PERMANOVA + B20 package ${ }^{79,80}$. Dataset manipulations, basic tests (t-tests)

193 and others graphical visualizations were performed in R Environment ${ }^{81}$ using the library

$194 \operatorname{ggplot} 2^{82}$.

195

196 Results

197

Typology of habitats

199 Mean habitat descriptors significantly differed between the habitat types a priori defined, while

200 Period and the interaction (Habitat x Period) had no significant effect (PERMANOVA, P-value <

2010.001 , Table 3, Fig. 2). Among the 91 habitat pairs, 88 pair-wise tests resulted in a significant

202 difference of descriptor assemblage between pairs of habitat types (PERMANOVA, pair-wise

203 tests, all $\mathrm{P}<0.1$ ). Such results a posteriori confirmed the validity of the 14 habitat types defined

204 for the fixed factor "habitat", which remained stable over time whatever the season. These

205 habitat types could be grouped into 3 main categories: rocky substrates, soft bottoms and

206 seagrass beds, with all their interfaces. 
207 The first two axes of the PCoA explained $63.4 \%$ of the variance ( $81.7 \%$ for the first five axes).

208 Rocky substrates (natural and artificial) gathered tightly on the positive part of axis 1 and were

209 correlated not only with rocks and boulders, but also with high slope, high rugosity, and most

210 macrophyte categories. Natural rocky habitats (RS) were characterized in particular by

211 Cystoseira forests (21\% mean coverage), other arborescent macroalgae (7\%; i.e. Halopitys

212 incurvus), and bushland communities (49\%; i.e. Sphacelariales) (Table S1). Artificial rocky

213 substrates (AR) differed from natural ones by the absence of any type of erect perennial

214 macrophyte forest, but the amount of turf /encrusting algae cover (42\%) and bushland (58 \%).

215 All soft bottoms (SB) clustered on the positive part of axis 2 and were mainly correlated with

216 gravel and floating algal detritus. They were scattered along axis 1 from pebbles (positive part)

217 to sand (negative part) depending on their granulometry. They were also characterized by a low

218 slope and the absence or rarity of algal cover (5\% of turf/encrusting algae only). Unlike rocky or

219 soft bottoms, seagrass bed habitats, and particularly those associated with Posidonia oceanica

220 (PO), were highly dispersed on the PCoA plan (Fig. 2), in relation with the type of substrate $P$.

221 oceanica is growing on. Stations where $P$. oceanica was growing on rocky substrates clustered

222 on the positive part of axis 1, but on the negative part of axis 1 where it was growing on sandy

223 substrates. Habitats associated with $P$. oceanica barrier reef structure were scattered along axis 2

224 from high depth and seagrass cover percentage on the barrier reef outer slope (POEX) to a high

225 percentage of sand in the shallow inner slope (POIN) and associated Cymodocea nodosa

226 meadows (CY and POCY). POIN was also characterized by the presence of algal wrack, which

227 offered shelter to juvenile fish.

228 On the plan defined by axes 1 and 2, some PODM stations were gathered with rocky habitats due 229 to a high cover percentage of macrophytes, especially bushland communities (Table S1), but all 
230 PODM stations tightly clustered together on the positive part of axis 4, which was correlated

231 with a high dead matte percentage. All interfaces were positioned on the PCoA plan at a logical

232 but well-individualized place testifying to their particular identity: IPR between Posidonia and

233 rocky substrates on the positive part of axis 1 and negative part of axis 2, IRS between rocky and

234 soft substrates on the positive parts of both axes, IPS and IPM on the negative part of axis 1, as

235 correlated to high sand and dead matte percentages respectively. Mean values $( \pm \mathrm{SE})$ of the

236 abiotic and biotic descriptors of the 14 individualized habitat types are given in Table S1, along

237 with their significant seasonal variations. Abiotic descriptors rarely changed with period

238 whatever the habitat and were related to the haphazard position of sampling units, while biotic

239 habitat descriptors presented consistent seasonal variations linked to the biology and growth of

240 macrophytes. Higher cover percentages and canopy height of seagrasses and macroalgae were

241 generally recorded in warm rather than in cold period, except for turf/encrusting and wrecked

242 algae, which increased the three-dimensional structure of these habitats (Table S1). However,

243 differences were statistically significant only in a few habitats due to the high variance of data.

Juvenile fish assemblages

246 A total of 526014 juvenile individuals, belonging to 57 different fish species/taxa and 22

247 families were recorded (Table S2). As small juveniles of particular genera such as Symphodus, or

248 families such as blenniids and gobiids, were difficult to identify precisely underwater, they were

249 grouped into 41 taxa for analysis. A higher total species richness of juvenile fish was recorded

250 during the warm (37 taxa, $n=1376)$ than the cold (27 taxa, $n=725)$ period and differed among

251 habitats (Table 4). The highest total number of taxa was recorded on soft bottoms ( 25 taxa, $\mathrm{n}=$

252 426), followed by rocky substrates and Posidonia beds (22 taxa each, $\mathrm{n}=428)$, while the lowest 
253 number of juvenile fish species was observed in Cymodocea beds ( 6 taxa, $\mathrm{n}=116)$. The most

254 abundant taxa included by decreasing order of importance unidentified larvae, Atherina sp.,

255 Sarpa salpa, Gobiidae, Symphodus spp., Diplodus vulgaris, Pagellus spp., Diplodus annularis,

256 Oblada melanura and Diplodus sargus (Fig. 3). They were observed in most habitats (from 7

257 habitats for Pagellus spp. to 14 for D. vulgaris), while 13 taxa were recorded in only one habitat

258 type, generally with low abundance (Table S3). Four taxa were only recorded on rocky substrates

259 (Boops boops, Epinephelus marginatus, Thalassoma pavo and Tripterygiidae) and four on soft

260 bottoms (Arnoglossus spp., Bothus sp., Solea sp. and Trachinidae). Most species (23 spp.) were

261 observed at both periods, and a higher number were recorded only in warm than only in cold

262 periods (14 spp. vs 4 spp., respectively) (Fig. 3).

263 Mean species richness varied from 0.25 to 3 taxa per $10 \mathrm{~m}^{2}$ and differed according habitats and

264 periods. The significant interaction of the two factors indicated that between-habitat variability

265 differed between seasons (PERMANOVA, $\mathrm{F}=6.506, \mathrm{P}<0.001$, Table 5). Mean species

266 richness was highest on natural and artificial rocky substrates and lowest in Cymodocea beds

267 (Fig. 4). Interfaces Posidonia/other habitats (IPR, IPS and IPM) presented a higher mean species

268 richness than the different habitats of $P$. oceanica bed and barrier reef, demonstrating the

269 particular importance of ecotones for juvenile fishes. The mean species richness tended to be

270 higher during the warm than the cold period, in all but POIN habitat, where a lower mean species

271 richness was recorded in summer (data not shown).

272 As schools of larvae and Atherina sp. could be numerous and haphazardly dispersed in space and

273 time, they might mask the effect of period or habitat on relative abundance. Atherina sp. were

274 more abundant during the warm period and were present in 12 habitats, while undetermined

275 larvae were observed in higher abundance during the cold period and present in 13 habitat types. 
276 They were thus excluded from the analysis of juvenile abundance to obtain clearer patterns. The

277 total density of juvenile fishes also varied significantly between habitats and periods, with

278 different patterns according to the period (PERMANOVA, F =6.028, $\mathrm{P}<0.001$; Fig. 5; Table

279 6). In most habitats, except POIN and IPS, juvenile fish abundance was higher during the warm

280 season, especially in Posidonia seagrass beds and barrier reef outer slope (POEX) and lagoon

281 (POCY). The mean abundance of juvenile fish, all habitats combined, did not differ significantly

282 with period (Table 6), reaching $8.48 \pm 0.69$ individuals per $10 \mathrm{~m}^{2}$ during the warm period and

$2839.59 \pm 0.94$ individuals per $10 \mathrm{~m}^{2}$ during the cold period.

284

285

Variability of juvenile fish assemblages in habitats

286 The assemblage composition of juvenile fishes in terms of relative taxa-specific densities

287 significantly differed between periods, and these differences were specific to each habitat as a

288 significant interaction between the two factors was evidenced (PERMANOVA, F = 7.743,

$289 \mathrm{P}<0.001$; Fig. 6 ; Table 7). Seasonal differences in juvenile assemblage occurred in most habitat

290 types, except CY, POCY and IRS. On rocky substrates (RS), no difference in juvenile fish

291 assemblage according to the relative importance of macroalgal cover types (Cystoseira forest,

292 bushland or turf/encrusting) was observed (PERMANOVA, $\mathrm{F}=0.87, \mathrm{p}=0.531$ ). While the

293 assemblage differed with period (pair-wise test, $\mathrm{t}=1.594, \mathrm{p}=0.025$ ), Sarpa salpa was the

294 dominant species in both periods, followed by Diplodus annularis, Boops boops and Symphodus

295 spp. in the warm period, and by D. sargus, Mugil spp., and Thalassoma pavo in the cold period

296 (Fig. 6). S. salpa also dominated on artificial structures (AR) in warm period, with Symphodus

297 spp., Oblada melanura and Coris julis. On soft bottoms (SB), Gobiidae followed by S. salpa

298 dominated in both periods, while the assemblage statistically differed $(\mathrm{t}=3.406, \mathrm{p}<0.001)$. 
During the warm period, Mugil spp., D. sargus and D. puntazzo were also abundant on SB and

300

301

302

303

304

305

306

307

308

309

310

311

312

313

314

315

316

317

318

319

320

321

particularly associated with high percentages of pebbles and gravel, while Pagellus spp.,

Lithognathus mormyrus, Mullus spp., Trachinidae, Bothus sp. and Solea sp. were more

associated with sand. During the cold period, D. vulgaris was particularly abundant on SB and mainly associated with pebbles and gravel. In Posidonia beds (PO), the juvenile fish assemblage

slightly differed according to the type of substrate $P$. oceanica was growing on. Higher abundances of D. annularis and Symphodus spp. were recorded when the seagrass was growing on sand, and of $O$. melanura and $S$. salpa when growing on rocky substrates. A seasonal variation was observed in PO $(\mathrm{t}=3.298, \mathrm{p}<0.001)$ with high abundances of Pagellus spp., $S$. salpa, Symphodus spp. during the warm period, and the dominance of D. vulgaris in the cold period. Oblada melanura remained abundant all the year in PO. In the different barrier reef habitats, the juvenile assemblage differed with periods, while some species dominated in both periods, such as $S$. salpa in POBR $(\mathrm{t}=2.335, \mathrm{p}<0.001)$ and $\operatorname{PODM}(\mathrm{t}=2.048, \mathrm{p}=0.007)$, Symphodus spp. in POEX $(\mathrm{t}=2.651, \mathrm{p}<0.001)$, and Gobiidae plus Pagellus spp. in POIN $(\mathrm{t}=$ 3.174, $\mathrm{p}<0.001$ ) (Fig. 6). Each type of interface was dominated by the abundance of some species, and presented seasonal variations, except IRS $(\mathrm{t}=1.101, \mathrm{p}=0.289)$ dominated by Gobiidae, Serranus cabrilla and O. melanura. At IPR, C. julis was the dominant species in both periods, but with a far higher abundance in the warm period $(\mathrm{t}=2.083, \mathrm{p}=0.005)$ followed by O. melanura and Symphodus spp., and by S. salpa and S. cabrilla in the cold period. At IPS, the juvenile assemblage was dominated by Symphodus spp., D. annularis, and O. melanura during the warm period, and by Gobiidae, D. vulgaris and Pagellus spp. in the cold period $(\mathrm{t}=1.608, \mathrm{p}$ $=0.038$ ). At IPM, the dominant species was $S$. salpa in the warm period, and Symphodus spp. in the cold period $(\mathrm{t}=3.331, \mathrm{p}<0.001)$. Noteworthy was the higher presence of predators 
322 (Serranus cabrilla, S. scriba, Scorpaena porcus, Dentex dentex and Labrus viridis) in interface

323 habitats (Fig. 6). In Cymodocea meadows (CY and POCY) no statistical difference was observed 324 with period $(\mathrm{t}=1.221, \mathrm{p}=0.212$ and $\mathrm{t}=1.297, \mathrm{p}=0.162$, respectively $)$ and the assemblage was 325 dominated by D. vulgaris in CY and by Pagellus spp., D. vulgaris and Gobiidae in POCY. Thus, 326 several species dominated in different juvenile habitats in both periods. However, the mean size 327 of juvenile fishes could differ between periods as illustrated in Fig. 7 for some of the most 328 abundant species. Smaller-sized juveniles were observed during the warm period for $D$.

329 annularis, D. sargus, O. melanura and Pagellus spp., and during the cold period for D. vulgaris 330 and S. salpa.

\section{Discussion}

\section{Habitats used by juvenile fish in Mediterranean shallow coastal zones}

335

All the sites surveyed hosted juveniles whatever the period, highlighting the crucial functional role of the very shallow coastal bottoms as fish nurseries. In contrast to findings based on the habitat- and species-centered approaches, in the present study juvenile fish assemblages were recorded in all types of habitats encountered in Mediterranean shallow coastal zone. A total of 14 different habitat types were characterized, which could be grouped into three broad categories, rocky substrates (natural RS and artificial AR), sedimentary bottoms (SB) with all levels of granulometry, and seagrass beds including Cymodocea nodosa and Posidonia oceanica meadows (CY, PO, PODM) (Table 1). The ecotones or interfaces between the three broad habitat categories (IPM, IPR, IPS and IRS), were individualized as particular habitat types. We evidenced that if the structural characteristics of habitat types did not vary with period, the 
345 biological characteristics did vary with higher cover percentages and canopy height of seagrasses

346 and macroalgae in the warm period (Table S1).

347 The presence of juveniles was evidenced in every type of sampled habitat. While the habitat

348 types were well individualized, it appeared that one third of fish species occupied more than 7

349 habitat types when juveniles and were the most abundant species (34.1\% of total species

350 richness and $95.2 \%$ of total abundance), while the one third of species characteristic of only one

351 habitat type were rather rare (31.7\% of total species richness and $1.1 \%$ of total abundance). If

352 atherinids and larvae were excluded, the relative abundance of the common and restricted species

353 remained similar (90.8\% and $2.0 \%$ respectively). Habitat and seascape tri-dimensional structure

354 can be qualified by its heterogeneity and complexity ${ }^{83,84}$. Generally high quality habitats for

355 juvenile fishes are recognized to be associated with high degrees of three-dimensional

356 structuration ${ }^{85}$, in terms of both complexity ${ }^{46,48,86,87}$ and/or heterogeneity ${ }^{36}$. Natural rocky

357 habitats (RS) presented a high structural and biological complexity due to different macrophytes

358 assemblages, and indeed supported the highest mean species richness and abundance of juvenile

359 fishes whatever the period. However, SB while presenting a lower structural complexity than RS

360 or PO, supported the highest total species richness (24 spp.) of juvenile fish owing to an

361 intermixed diversity of granulometry and the ability it offers to the juveniles to blend in with the

362 bottom. It was also evidenced that interfaces represented highly favorable habitats for juveniles

363 in terms of both species richness and abundance (Fig. 4 and 5). Ecotones (i.e. interfaces) have

364 long been known as increasing the diversity of fish communities ${ }^{88}$ and their role in the dynamics

365 of rocky fish assemblages associated with Cystoseira forests was recently studied in the

366 Mediterranean Sea ${ }^{47,89}$. Interfaces, particularly between Posidonia beds and adjacent habitats

367 (IPS, IPR, IPM), harbored a high number of juveniles of piscivorous fishes such as Serranus 


7

cabrilla, Scorpaena porcus, Dentex dentex, and Labrus viridis, which found here a suitable place for predation. This is consistent with previous studies highlighting the suitability of ecotones for various predation strategies (ambush, stalk-attack, etc.) ${ }^{89}$ and for avoidance of predators by their juvenile prey ${ }^{87}$. In the case of the Posidonia oceanica barrier reef complex, we provided evidence that different juvenile fish assemblages were associated with the different parts of the barrier reefs including reef flat, slopes and lagoon (POBR, POEX, POIN, and POCY). The barrier reef complex is by nature a juxtaposition of various habitat patches along with their interfaces; this habitat diversity allows various species to find suitable juvenile habitats, as illustrated in the case of tropical reef habitat systems ${ }^{90,91}$.

\section{Temporal succession of nursery use by juvenile fishes}

We observed that juvenile fish assemblages presented higher species richness and abundance during the warm than the cold period in most habitat types. The specific composition of the juvenile assemblage is directly linked to the reproductive cycle of coastal fish species. Juvenile fishes settling in coastal nurseries during the warm period were issued from adults reproducing in spring or early summer, as the duration of larval life for most Mediterranean coastal fish species ranges from 2 to 6 weeks ${ }^{15,59,92}$. Those arriving during the cold period resulted from the reproduction of adults in late summer, autumn and winter. We observed in effect the smallest $D$. annularis and $D$. sargus juveniles during the warm period and the smallest $D$. vulgaris and $S$. salpa during the cold period (Fig. 7), following a well-known temporal succession of juvenile fish species in coastal nurseries ${ }^{26,42,56,64,68,93}$. If juvenile fishes settle sometimes in highly specific habitats, they rapidly expand their home range when growing and increasing their swimming capacities, colonizing deeper or adjacent habitats ${ }^{20}$, and leaving settlement sites available for the 
391 successive arrival of fish post-larvae $e^{54,56,93}$. By performing such ontogenetic habitat shifts as they 392 grow, juveniles tend to switch to using the habitat best fitting their needs in terms of food versus 393 refuge against predation availability (the "habitat quality" ratio) ${ }^{19}$. We observed in effect the 394 presence of juveniles of $>34 \%$ fish species in more than half of the habitat types individualized 395 indicating that they were used by fishes at various stages of their juvenile life. Thus, for most 396 species, the presence of a mosaic of different habitats is essential for the success of juvenile fish 397 recruitment ${ }^{46,47}$.

\section{Importance of both local habitat characteristics and large-scale environmental}

\section{conditions}

401 However, the higher abundance of juveniles in seagrass bed habitats and rocky substrates during 402 the warm period could be related to the greater protection and food resources provided by the 403 greater canopy height of Posidonia oceanica and macroalgae communities ${ }^{45,46,48}$. The role of 404 highly complex Cystoseira forest canopies with regard to the composition of juvenile fish assemblage was well studied by Cheminée et al. ${ }^{45,46}$, Cuadros et al. ${ }^{47}$ and Hinz et al. ${ }^{48}$, who 406 demonstrated that Symphodus spp., Labrus spp. and Serranus spp. were more abundant in dense

407 complex forests, while $C$. julis and T. pavo preferred less complex patches of bare substratum 408 located at the edges of the forests. In our study, Cystoseira forests where not extensive enough to 409 form large, dense forests such as those studied by these authors in Corsica and the Balearic 410 Islands, but were mixed with patches of other erect macroalgae, bushland and turf algae. This 411 was the reason why no correlation was found between the cover percentages of these macrophyte 412 assemblages and the composition of the juvenile fish assemblages on the coasts of Western 413 Provence (authors' unpublished data). The decline and scarcity of erect macroalgae forests 
414 (notably Cystoseira spp.) has been documented in the last two decades in different parts of the

415 Mediterranean coasts ${ }^{94-97}$. Decline of forests occurs through ecosystem shifts resulting from

416 cascading effects from a wide array of anthropogenic pressures ${ }^{98-100}$. Such profound

417 transformations of the seascape is known to have damaging effects on habitats' nursery

418 role $\mathrm{e}^{45,47,49,72}$. Therefore, in those altered areas, the habitat quality available nowadays for juvenile

419 fishes is probably several orders of magnitude below what it could be $\mathrm{e}^{46}$. This highlights the

420 importance of preserving what is left of the nursery function of coastal areas. In order to preserve

421 this function, habitats should in particular be protected against destruction but also against any

422 kind of transformation of their tri-dimensional structure and composition.

423 On the other hand, juvenile fishes' abundance ${ }^{56}$, growth ${ }^{101}$ and mortality ${ }^{102}$ vary considerably in

424 space and time due to natural stochastic processes linked to both environmental conditions

425 (currents, winds, hydrological parameters) ${ }^{44,53}$ and the success of adult reproduction ${ }^{103}$, being

426 high or low at one place from one year to another. The same nursery site can therefore perform

427 as a 'good' nursery site one year and not the following one ${ }^{56}$. Similarly, the same habitat can

428 perform as a 'good' nursery at a given site but not in another location ${ }^{104}$. Thus, the success of

429 fish nurseries does not depend only on the local characteristics of habitats but also on large scale

430 environmental phenomena that determine the initial intensity and trajectory of the flux of fish

$431 \operatorname{larvae}^{71,105}$.

432

Importance of the mosaic of habitats for coastal fishes

434 We provided evidence that the most abundant fish species in Mediterranean shallow coastal

435 areas used several habitat types as nurseries whatever the period, even if juvenile fish

436 assemblages presented specificities in composition and relative abundance of species in each 
437 habitat type (Fig. 6). It could be thus claimed that all habitat types present an actual potential as

438 nursery sites for Mediterranean coastal fishes, and that a diversified mosaic of habitats would be

439 the most efficient way to promote high and successful juvenile fish recruitment by providing

440 contiguous shelters and food resources for the different stages of fishes' juvenile life. These

441 results are in agreement with the seascape nursery approach developed by Nagelkerken et al. ${ }^{106}$,

442 which conceptualizes the role of functionally connected multiple mosaics of habitats for fish

443 nursery management.

444 The effective management of coastal zones often consists in a non-fair trade-off between

445 destructive or impacting human activities (harbor and marina constructions, sewage and

446 industrial outflow, etc.) and efforts for environmental protection mainly represented by the

447 implementation of marine protected areas ${ }^{107,108}$. A pernicious consequence of the current

448 awareness of the economic value of ecosystems and their ecological services to human

449 populations ${ }^{109}$ often resides in a hierarchical view of ecosystems or habitats depending on the

450 intended goals of users. For example, in the Mediterranean Sea Posidonia oceanica seagrass

451 beds benefit from a particular protection status ${ }^{110}$, and coralligenous reefs merit special

452 attention ${ }^{111}$. The results of the present study evidence the importance of all types of shallow

453 coastal habitats as nursery sites for Mediterranean fishes whatever the period considered, which

454 strongly supports the general seascape nursery theory of Nagelkerken et al. ${ }^{106}$ and the views of

455 Cheminée et al. ${ }^{112}$ and Cuadros et al. ${ }^{47}$ for the Mediterranean Sea, regarding the importance of

456 protecting the mosaic of habitats for the good health and functioning of coastal ecosystems. The

457 preservation of a mosaic of habitats along the coast, notably in very shallow waters, therefore

458 constitutes the best way to preserve both fish biodiversity and fishery resources. This study

459 highlights that conservation in France is often disconnected from biological reality with, except 
460 in a few Marine Parks (which represent a small portion of coastline ${ }^{113}$ ), most of the shallow

461 habitats not taken into account in any protection plan.

462

463

464

465 References

466 1. Costanza, R. et al. Changes in the global value of ecosystem services. Glob. Environ.

$467 \quad$ Change 26, 152-158 (2014).

468 2. Costanza, R. et al. The value of the world's ecosystem services and natural capital. nature $469 \quad 387,253-260(1997)$.

470 3. Halpern, B. S. et al. A Global Map of Human Impact on Marine Ecosystems. Science 319, $471948-952(2008)$.

472 4. Lindeboom, H. The coastal zone: an ecosystem under pressure. Oceans 2020 Sci. Trends $473 \quad$ Chall. Sustain. 49-84 (2002).

474 5. Airoldi, L., Balata, D. \& Beck, M. W. The Gray Zone: Relationships between habitat loss 475 and marine diversity and their applications in conservation. J. Exp. Mar. Biol. Ecol. 366, 8$476 \quad 15(2008)$.

477 6. Islam, S. \& Tanaka, M. Impacts of pollution on coastal and marine ecosystems including 478 coastal and marine fisheries and approach for management: a review and synthesis. Mar. 479 Pollut. Bull. 48, 624-649 (2004).

480 7. Vikas, M. \& Dwarakish, G. S. Coastal Pollution: A Review. Aquat. Procedia 4, 381-388 $481 \quad(2015)$. 
482 8. Blaber, S. J. M. et al. Effects of fishing on the structure and functioning of estuarine and nearshore ecosystems. ICES J. Mar. Sci. 57, 590-602 (2000).

9. Hussein, C. et al. Assessing the impact of artisanal and recreational fishing and protection on 485 a white seabream (Diplodus sargus sargus) population in the north-western Mediterranean Sea using a simulation model. Part 1: Parameterization and simulations. Fish. Res. 108, 163-

10. Hawkins, A. D. \& Popper, A. N. A sound approach to assessing the impact of underwater noise on marine fishes and invertebrates. ICES J. Mar. Sci. 74, 635-651 (2017).

490

11. Beck, M. W. et al. The Identification, Conservation, and Management of Estuarine and Marine Nurseries for Fish and Invertebrates. BioScience 51, 633-641 (2001).

12. Carr, M. H. Habitat selection and recruitment of an assemblage of temperate zone reef fishes.

13. Sheaves, M., Baker, R. \& Johnston, R. Marine nurseries and effective juvenile habitats: an J. Exp. Mar. Biol. Ecol. 146, 113-137 (1991). alternative view. Mar. Ecol. Prog. Ser. 318, 303-306 (2006).

14. Leis, J. M. Are Larvae of Demersal Fishes Plankton or Nekton? in Advances in Marine Biology vol. 51 57-141 (Academic Press, 2006).

15. Raventos, N. \& Macpherson, E. Planktonic larval duration and settlement marks on the 499 otoliths of Mediterranean littoral fishes. Mar. Biol. 138, 1115-1120 (2001).

500 16. Di Franco, A. et al. Dispersal of larval and juvenile seabream: Implications for 501 Mediterranean marine protected areas. Biol. Conserv. 192, 361-368 (2015).

502 17. Di Franco, A. et al. Assessing Dispersal Patterns of Fish Propagules from an Effective 503 Mediterranean Marine Protected Area. PLoS ONE 7, e52108 (2012).

504 18. Di Franco, A. \& Guidetti, P. m. Biol. Lett. 7, 454-456 (2011). 
505 19. Dahlgren, C. P. \& Eggleston, D. B. Ecological processes underlying ontogenetic habitat 506 shifts in a coral reef fish. Ecology 81, 2227-2240 (2000).

507 20. Macpherson, E. Ontogenetic shifts in habitat use and aggregation in juvenile sparid fishes. $J$. $508 \quad$ Exp. Mar. Biol. Ecol. 220, 127-150 (1998).

509 21. Dahlgren, C. P. et al. Marine nurseries and effective juvenile habitats: concepts and $510 \quad$ applications. Mar. Ecol. Prog. Ser. 312, 291-295 (2006).

511 22. Jennings, S. \& Blanchard, J. L. Fish Abundance with No Fishing: Predictions Based on 512 Macroecological Theory. J. Anim. Ecol. 73, 632-642 (2004).

513 23. Jones, G. P. The Importance of Recruitment to the Dynamics of a Coral Reef Fish $514 \quad$ Population. Ecology 71, 1691-1698 (1990).

515 24. Sheaves, M., Baker, R., Nagelkerken, I. \& Connolly, R. M. True Value of Estuarine and 516 Coastal Nurseries for Fish: Incorporating Complexity and Dynamics. Estuaries Coasts 38, $517 \quad 401-414(2015)$.

518 25. Harmelin-Vivien, M. L., Harmelin, J. G. \& Leboulleux, V. Microhabitat requirements for 519 settlement of juvenile Sparid fishes on Mediterranean rocky shores. Hydrobiologia 301, $520 \quad 309-320(1995)$.

521 26. Garcia-Rubies, A. \& Macpherson, E. Substrate use and temporal pattern of recruitment in 522 juvenile fishes of the mediterranean littoral. Mar. Biol. 124, 35-42 (1995).

523 27. Macpherson, E. \& Zika, U. Temporal and spatial variability of settlement success and 524 recruitment level in three blennoid fishes in the northwestern Mediterranean. Mar. Ecol.525 Prog. Ser. 182, 269-282 (1999).

526 28. Heck, K., Hays, G. \& Orth, R. Critical evaluation of the nursery role hypothesis for seagrass 527 meadows. Mar. Ecol. Prog. Ser. 253, 123-136 (2003). 
29. Mosconi, P. \& Chauvet, C. Growth spatio-temporal variability of juveniles of seabream(Sparus aurata) between lagoonal and sea areas in the south of Lion's Gulf. Vie Milieu Paris 40, 305-311 (1990).

30. Verdiell-Cubedo, D., Oliva-Paterna, F. J., Ruiz-Navarro, A. \& Torralva, M. Assessing the nursery role for marine fish species in a hypersaline coastal lagoon (Mar Menor, Mediterranean Sea). Mar. Biol. Res. 9, 739-748 (2013).

31. Letourneur, Y., Darnaude, A., Salen-picard, C. \& Harmelin-vivien, M. Spatial and temporal variations of fish assemblages in a shallow Mediterranean soft-bottom area (Gulf of Fos, France). Oceanol. Acta 24, 273-285 (2001).

32. Le Pape, O. et al. Sources of organic matter for flatfish juveniles in coastal and estuarine nursery grounds: A meta-analysis for the common sole (Solea solea) in contrasted systems of Western Europe. J. Sea Res. 75, 85-95 (2013).

33. Guidetti, P. \& Bussotti, S. Recruitment of Diplodus annularis and Spondyliosoma cantharus (Sparidae) in shallow seagrass beds along the Italian coasts (Mediterranean Sea). Mar. Life 7, 47-52 (1997).

34. Guidetti, P. \& Bussotti, S. Fish fauna of a mixed meadow composed by the seagrasses Cymodocea nodosa and Zostera noltii in the Western Mediterranean. Oceanol. Acta 23, 759770 (2000).

35. Guidetti, P. \& Bussotti, S. Effects of seagrass canopy removal on fish in shallow Mediterranean seagrass (Cymodocea nodosa and Zostera noltii) meadows: a local-scale approach. Mar. Biol. 140, 445-453 (2002).

36. Cuadros, A. et al. The three-dimensional structure of Cymodocea nodosa meadows shapes juvenile fish assemblages (Fornells Bay, Minorca Island). Reg. Stud. Mar. Sci. (2017). 
551 37. Francour, P. \& Le Direac'h, L. Recrutement de l'ichtyofaune dans l'herbier superficiel à

552 Posidonia oceanica de la réserve naturelle de Scandola (Corse, Méditerranée nordoccidentale): données préliminaires. Trav. Sci. Parc Nat. Régional Corse 46, 71-91 (1994).

38. Francour, P. \& Le Direac'h, L. Analyse spatiale du recrutement des poissons de l'herbier à Posidonia oceanica dans la réserve naturelle de Scandola (Corse, Méditerranée nord-

39. Francour, P. \& Le Direach, L. Le recrutement des poissons dans les herbiers à Posidonia oceanica : quels sont les facteurs influents? in 67-78 (1995).

40. Le Direac'h, L. \& Francour, P. Recrutement de Diplodus annularis (Sparidae) dans les Régional Corse 57, 42-75 (1998).

41. Guidetti, P. Differences Among Fish Assemblages Associated with Nearshore Posidonia oceanica Seagrass Beds, Rocky-algal Reefs and Unvegetated Sand Habitats in the Adriatic Sea. Estuar. Coast. Shelf Sci. 50, 515-529 (2000).

42. Félix-Hackradt, F. C., Hackradt, C. W., Treviño-Otón, J., Pérez-Ruzafa, A. \& GarcíaCharton, J. A. Temporal patterns of settlement, recruitment and post-settlement losses in a rocky reef fish assemblage in the South-Western Mediterranean Sea. Mar. Biol. 160, 23372352 (2013).

43. Félix-Hackradt, F. C., Hackradt, C. W., Treviño-Otón, J., Pérez-Ruzafa, Á. \& GarcíaCharton, J. A. Habitat use and ontogenetic shifts of fish life stages at rocky reefs in Southwestern Mediterranean Sea. J. Sea Res. 88, 67-77 (2014). 
573 44. Félix-Hackradt, F. C. et al. Environmental determinants on fish post-larval distribution in

$574 \quad$ coastal areas of south-western Mediterranean Sea. Estuar. Coast. Shelf Sci. 129, 59-72

$575 \quad(2013)$.

576 45. Cheminée, A. et al. Nursery value of Cystoseira forests for Mediterranean rocky reef fishes.

577 J. Exp. Mar. Biol. Ecol. 442, 70-79 (2013).

578 46. Cheminée, A. et al. Juvenile fish assemblages in temperate rocky reefs are shaped by the 579 presence of macro-algae canopy and its three-dimensional structure. Sci. Rep. 7, 14638

$580 \quad$ (2017).

581 47. Cuadros, A. et al. Juvenile fish in Cystoseira forests: influence of habitat complexity and

582 depth on fish behaviour and assemblage composition. Mediterr. Mar. Sci. 20, 380-392

$583 \quad$ (2019).

584 48. Hinz, H., Reñones, O., Gouraguine, A., Johnson, A. F. \& Moranta, J. Fish nursery value of 585 algae habitats in temperate coastal reefs. PeerJ 7, e6797 (2019).

586 49. Thiriet, P. D. et al. Abundance and Diversity of Crypto- and Necto-Benthic Coastal Fish Are 587 Higher in Marine Forests than in Structurally Less Complex Macroalgal Assemblages. PLOS $588 \quad$ ONE 11, e0164121 (2016).

589 50. Cheminée, A. et al. Shallow rocky nursery habitat for fish: Spatial variability of juvenile 590 fishes among this poorly protected essential habitat. Mar. Pollut. Bull. 119, 245-254 (2017).

591 51. Mercader, M. et al. Spatial distribution of juvenile fish along an artificialized seascape, 592 insights from common coastal species in the Northwestern Mediterranean Sea. Mar. Environ. $593 \quad$ Res. (2018) doi:10.1016/j.marenvres.2018.02.030.

594 52. Tournois, J. et al. Lagoon nurseries make a major contribution to adult populations of a 595 highly prized coastal fish. Limnol. Oceanogr. 62, 1219-1233 (2017). 
53. Cuadros, A. et al. Settlement and post-settlement survival rates of the white seabream (Diplodus sargus) in the western Mediterranean Sea. PLOS ONE 13, e0190278 (2018).

54. Cheminée, A., Francour, P. \& Harmelin-Vivien, M. Assessment of Diplodus spp. (Sparidae) nursery grounds along the rocky shore of Marseilles (France, NW Mediterranean). Sci. Mar. 75, 181-188 (2011).

55. Pastor, J., Koeck, B., Astruch, P. \& Lenfant, P. Coastal man-made habitats: Potential nurseries for an exploited fish species, Diplodus sargus (Linnaeus, 1758). Fish. Res. 148, 7480 (2013).

56. Vigliola, L. et al. Spatial and temporal patterns of settlement among sparid fishes of the genus Diplodus in the northwestern Mediterranean. Mar. Ecol.-Prog. Ser. 168, 45-56 (1998).

57. Vigliola, L. \& Harmelin-Vivien, M. Post-settlement ontogeny in three Mediterranean reef fish species of the Genus Diplodus. Bull. Mar. Sci. 68, 271-286 (2001).

58. Morat, F. et al. Diet of the mediterranean european shag, Phalacrocorax aristotelis desmarestii, in a northwestern mediterranean area: a competitor for local fisheries? Sci. Rep. Port-Cros Natl. Park 28, 113-132 (2014).

59. Morat, F. et al. Offshore-onshore linkages in the larval life history of sole in the Gulf of Lions (NW-Mediterranean). Estuar. Coast. Shelf Sci. 149, 194-202 (2014).

60. La Mesa, G., Louisy, P. \& Vacchi, M. Assessment of microhabitat preferences in juvenile dusky grouper (Epinephelus marginatus) by visual sampling. Mar. Biol. 140, 175-185 (2002). 
617 61. Vacchi, M., La Mesa, G., Finoia, M. G., Guidetti, P. \& Bussotti, S. Protection measures and 618 juveniles of dusky grouper, Epinephelus marginatus (Lowe, 1834)(Pisces, Serranidae), in the 619 Marine Reserve of Ustica Island (Italy, Mediterranean Sea). Mar Life 9, 63-70 (1999).

620 62. Bodilis, P., Ganteaume, A. \& Francour, P. Presence of 1 year-old dusky groupers along the 621 French Mediterranean coast. J. Fish Biol. 62, 242-246 (2003).

622 63. Bodilis, P., Ganteaume, A. \& Francour, P. Recruitment of the dusky grouper (Epinephelus 623 marginatus) in the north-western Mediterranean Sea. Cybium 27, 123-129 (2003).

64. Raventos, N. \& Macpherson, E. Environmental influences on temporal patterns of settlement in two littoral labrid fishes in the Mediterranean Sea. Estuar. Coast. Shelf Sci. 63, 479-487

65. Raventos, N. \& Macpherson, E. Effect of pelagic larval growth and size-at-hatching on post(2005).

66. Macpherson, E. \& Raventos, N. Settlement patterns and post-settlement survival in two Mediterranean littoral fishes: influences of early-life traits and environmental variables. Mar.

67. Biagi, F., Gambaccini, S. \& Zazzetta, M. Settlement and recruitment in fishes: The role of Biol. 148, 167-177 (2005).

\section{5} settlement survivorship in two temperate labrid fish of the genus Symphodus. Mar. Ecol.Prog. Ser. 285, 205-211 (2005). coastal areas. Ital. J. Zool. 65, 269-274 (1998).

68. Bussotti, S. \& Guidetti, P. Timing and habitat preferences for settlement of juvenile fishes in the Marine Protected Area of Torre Guaceto (south-eastern Italy, Adriatic Sea). Ital. J. Zool. 78, 243-254 (2011).

69. Franco, A. et al. Use of shallow water habitats by fish assemblages in a Mediterranean coastal lagoon. Estuar. Coast. Shelf Sci. 66, 67-83 (2006). 
640 70. Harmelin-Vivien, M. L. et al. Évaluation visuelle des peuplements et populations de

641 Poissons : méthodes et problèmes. Rev Ecol Terre Vie 40, 467-539 (1985).

642 71. Faillettaz, R. et al. Spatio-temporal patterns of larval fish settlement in the northwestern

643 Mediterranean Sea. Mar. Ecol. Prog. Ser. 1-13 (2020).

644 72. Cheminée, A. Ecological functions, transformations and management of infralittoral rocky

645 habitats from the North-western Mediterranean: the case of fish (Teleostei) nursery habitats.

646 (University of Nice, 2012).

647 73. Le Direach, L. et al. Programme NUhAGE :, nurseries, habitats, génie écologique, Rapport

648 final. Contrat GIS Posidonie - MIO - P2A développement / Agence de l'Eau Rhône-

649 Méditerranée-Corse - Conseil Général du Var. 1-146 (2015).

650 74. Cuadros, A. Settlement and post-settlement processes of Mediterranean littoral fishes:

651 influence of seascape attributes and environmental conditions at different spatial scales.

652 (Universidad de las Islas Baleares, 2015).

653 75. Orellana, S., Hernández, M. \& Sansón, M. Diversity of Cystoseira sensu lato (Fucales,

654 Phaeophyceae) in the eastern Atlantic and Mediterranean based on morphological and DNA

655 evidence, including Carpodesmia gen. emend. and Treptacantha gen. emend. Eur. J. Phycol.

$656 \quad 54,447-465(2019)$.

657 76. Ballesteros, E. Els vegetals i la zonació litoral: espècies, comunitats i factors que influeixen 658 en la seva distribució. (1992).

659 77. Medrano, A. et al. Ecological traits, genetic diversity and regional distribution of the 660 macroalga Treptacantha elegans along the Catalan coast (NW Mediterranean Sea). Sci. Rep.

$661 \quad \mathbf{1 0}, 19219(2020)$. 
662 78. Clarke, K. R., Gorley, R. N., Somerfield, P. J. \& Warwick, R. M. Change in marine

663 communities: an approach to statistical analysis and interpretation. (Primer-E Ltd, 2001).

664 79. Clarke, K. R. \& Gorley, R. N. Primer v6: User Manual/Tutorial - Primer-E Ltd. 190 pp

$665 \quad$ (2006).

666 80. Anderson, M., Gorley, R. \& Clarke, K. PERMANOVA+ for PRIMER: guide to software and $667 \quad$ statistical methods. (Primer-e, 2008).

668 81. R Core Team. R: A language and environment for statistical computing. (R Foundation for 669 Statistical Computing., 2017).

670 82. Wickham, H. ggplot2: Elegant Graphics for Data Analysis. (Springer Science \& Business 671 Media, 2009).

672 83. August, P. V. The role of habitat complexity and heterogeneity in structuring tropical 673 mammal communities. Ecology 64, 1495-1507 (1983).

674 84. Wedding, L. M., Lepczyk, C. A., Pittman, S. J., Friedlander, A. M. \& Jorgensen, S. 675 Quantifying seascape structure: extending terrestrial spatial pattern metrics to the marine 676 realm. Mar. Ecol. Prog. Ser. 427, 219-223 (2011).

677 85. Thiriet, P., Cheminée, A., Mangialajo, L. \& Francour, P. How 3D Complexity of 678 Macrophyte-Formed Habitats Affect the Processes Structuring Fish Assemblages Within 679 Coastal Temperate Seascapes? in Underwater Seascapes (eds. Musard, O. et al.) 185-199 680 (Springer International Publishing, 2014).

681 86. Cheminée, A., Merigot, B., Vanderklift, M. A. \& Francour, P. Does habitat complexity 682 influence fish recruitment? Mediterr. Mar. Sci. 17, 39-46 (2016). 
87. Mercader, M. et al. Is artificial habitat diversity a key to restoring nurseries for juvenile coastal fish? Ex situ experiments on habitat selection and survival of juvenile seabreams. Restor. Ecol. 27, 1155-1165 (2019).

88. Winemiller, K. O. \& Leslie, M. A. Fish assemblages across a complex, tropical freshwater/marine ecotone. Environ. Biol. Fishes 34, 29-50 (1992).

89. Thiriet, P. Comparaison de la structure des peuplements de poissons et des processus écologiques sous-jacents, entre les forêts de Cystoseires et des habitats structurellement moins complexes, dans l'Infralittoral rocheux de Méditerranée nord-occidentale. (University of Nice, 2014).

90. Nagelkerken, I. et al. Importance of Mangroves, Seagrass Beds and the Shallow Coral Reef as a Nursery for Important Coral Reef Fishes, Using a Visual Census Technique. Estuar. Coast. Shelf Sci. 51, 31-44 (2000).

91. Adams, A. J. et al. Nursery function of tropical back-reef systems. Mar. Ecol.-Prog. Ser. 318, 287-301 (2006).

92. Vigliola, L., Harmelin-Vivien, M. \& Meekan, M. G. Comparison of techniques of backcalculation of growth and settlement marks from the otoliths of three species of Diplodus from the Mediterranean Sea. Can. J. Fish. Aquat. Sci. (2000) doi:10.1139/f00-055.

93. Ventura, D., Lasinio, G. J. \& Ardizzone, G. Temporal partitioning of microhabitat use among four juvenile fish species of the genus Diplodus (Pisces: Perciformes, Sparidae). Mar. Ecol. 36, 1013-1032 (2015).

94. Thibaut, T., Blanfune, A., Boudouresque, C. F. \& Verlaque, M. Decline and local extinction of Fucales in French Riviera: the harbinger of future extinctions? (2015). 
95. Thibaut, T., Pinedo, S., Torras, X. \& Ballesteros, E. Long-term decline of the populations of Fucales (Cystoseira spp. and Sargassum spp.) in the Alberes coast (France, North-western Mediterranean). Mar. Pollut. Bull. 50, 1472-1489 (2005).

96. Thibaut, T. et al. Unexpected Temporal Stability of Cystoseira and Sargassum Forests in Port-Cros, one of the Oldest Mediterranean Marine National Parks. Cryptogam. Algol. 37, 61-90 (2016).

97. Blanfuné, A., Boudouresque, C. F., Verlaque, M. \& Thibaut, T. The fate of Cystoseira crinita, a forest-forming Fucale (Phaeophyceae, Stramenopiles), in France (North Western Mediterranean Sea). Estuar. Coast. Shelf Sci. 181, 196-208 (2016).

98. Sales, M., Cebrian, E., Tomas, F. \& Ballesteros, E. Pollution impacts and recovery potential in three species of the genus Cystoseira (Fucales, Heterokontophyta). Estuar. Coast. Shelf Sci. (2011).

99. Sala, E., Boudouresque, C. F. \& Harmelin-Vivien, M. Fishing, trophic cascades, and the structure of algal assemblages: evaluation of an old but untested paradigm. Oikos 82, 425439 (1998).

100. Sala, E., Kizilkaya, Z., Yildirim, D. \& Ballesteros, E. Alien marine fishes deplete algal biomass in the Eastern Mediterranean. PLoS ONE 6, e17356 (2011).

101. Planes, S. et al. Spatio-temporal variability in growth of juvenile sparid fishes from the Mediterranean littoral zone. J. Mar. Biol. Assoc. U. K. 79, 137-143 (1999).

102. Macpherson, E. et al. Mortality of juvenile fishes of the genus Diplodus in protected and unprotected areas in the western Mediterranean Sea. Mar. Ecol. Prog. Ser. 160, 135-147 (1997). 
727 103. Pankhurst, N. W. \& Munday, P. L. Effects of climate change on fish reproduction and 728 early life history stages. Mar. Freshw. Res. 62, 1015-1026 (2011).

729 104. Cuadros, A. et al. Seascape attributes, at different spatial scales, determine settlement and 730 post-settlement of juvenile fish. Estuar. Coast. Shelf Sci. 185, 120-129 (2017).

731 105. Hidalgo, M. et al. Accounting for ocean connectivity and hydroclimate in fish

732 recruitment fluctuations within transboundary metapopulations. Ecol. Appl. 29, e01913 $733 \quad$ (2019).

734 106. Nagelkerken, I., Sheaves, M., Baker, R. \& Connolly, R. M. The seascape nursery: a novel 735 spatial approach to identify and manage nurseries for coastal marine fauna. Fish Fish. 16, $736 \quad 362-371(2015)$

737 107. Meinesz, A., Lefevre, J. R. \& Astier, J. M. Impact of coastal development on the 738 infralittoral zone along the southeastern Mediterranean shore of continental France. Mar. $739 \quad$ Pollut. Bull. 23, 343-347 (1991).

740 108. Boudouresque, C. F. et al. The Management of Mediterranean Coastal Habitats: A Plea for a Socio-ecosystem-Based Approach. in Evolution of Marine Coastal Ecosystems under the Pressure of Global Changes (eds. Ceccaldi, H.-J. et al.) 297-320 (Springer International

744 109. Seitz, R. D., Wennhage, H., Bergström, U., Lipcius, R. N. \& Ysebaert, T. Ecological 745 value of coastal habitats for commercially and ecologically important species. ICES J. Mar. Sci. 71, 648-665 (2014).

747 110. Boudouresque, C. F. et al. Protection and conservation of Posidonia oceanica meadows. 748 RAMOGE and RAC. (SPA publisher, Tunis, 2012). 
749 111. Sartoretto, S. et al. An integrated method to evaluate and monitor the conservation state 750 of coralligenous habitats: The INDEX-COR approach. Mar. Pollut. Bull. 120, 222-231

751

752

753

754

755

756

757

758

759

760

761

762

763

764

765

766

767

768

769

770

771 (2017).

112. Cheminée, A., Feunteun, E., Clerici, S., Bertrand, C. \& Francour, P. Management of infralittoral habitats: towards a seascape scale approach. in Underwater Seascapes - From geographical to ecological perspectives (eds. Musard, O., Francour, P. \& Feunteun, E.) 240 (Springer, 2014).

113. Meinesz, A. \& Blanfuné, A. 1983-2013: Development of marine protected areas along the French Mediterranean coasts and perspectives for achievement of the Aichi target. Mar. Policy 54, 10-16 (2015).

\section{Acknowledgments}

This study was funded by the Agence de l'Eau Rhône Méditerranée Corse, Délégation PACA et Corse-AGAF, and the Conseil Départemental du Var, Direction de l'Environnement, Service Mer et Littoral. We are grateful to the fishermen of Brusc, Cavalaire, Salins d'Hyères and Saint Tropez for discussions on fish nurseries, to Bérangère Casalta, Marion Thomassin and Grégory Sylla (Observatoire marin de la Communauté des Communes du golfe de Saint-Tropez) for technical assistance, to Priscilla Dupont and Félix Saul (P2A) for help in sampling campaigns, and to Prof. C.F. Boudouresque for scientific advice. Authors wish to thank M. Paul for revision of the English text. This project has received funding from the European FEDER fund $N^{\circ} 1166-$ 39417 for the MIO laboratory project. 


\section{Author Contributions}

773 All authors contributed extensively to the work presented in this paper. AC, LLD, ER, PA, AG, 774 AB, LC, JYJ, SR, TT and MHV performed the field work. AC, ER, PA, AG, DB, LC compiled 775 the data. AC, LLD and MHV analyzed output data. AC, LLD and MHV designed, wrote and 776 revised the manuscript. All authors discussed the results and implications and commented on the 777 manuscript at all stages.

778

779 Competing Financial Interests statement:

780 The authors declare no competing financial interests, and no non-financial competing interest.

\section{Additional Information}

783 Supplementary information accompanies this paper at http://www.nature.com/srep 


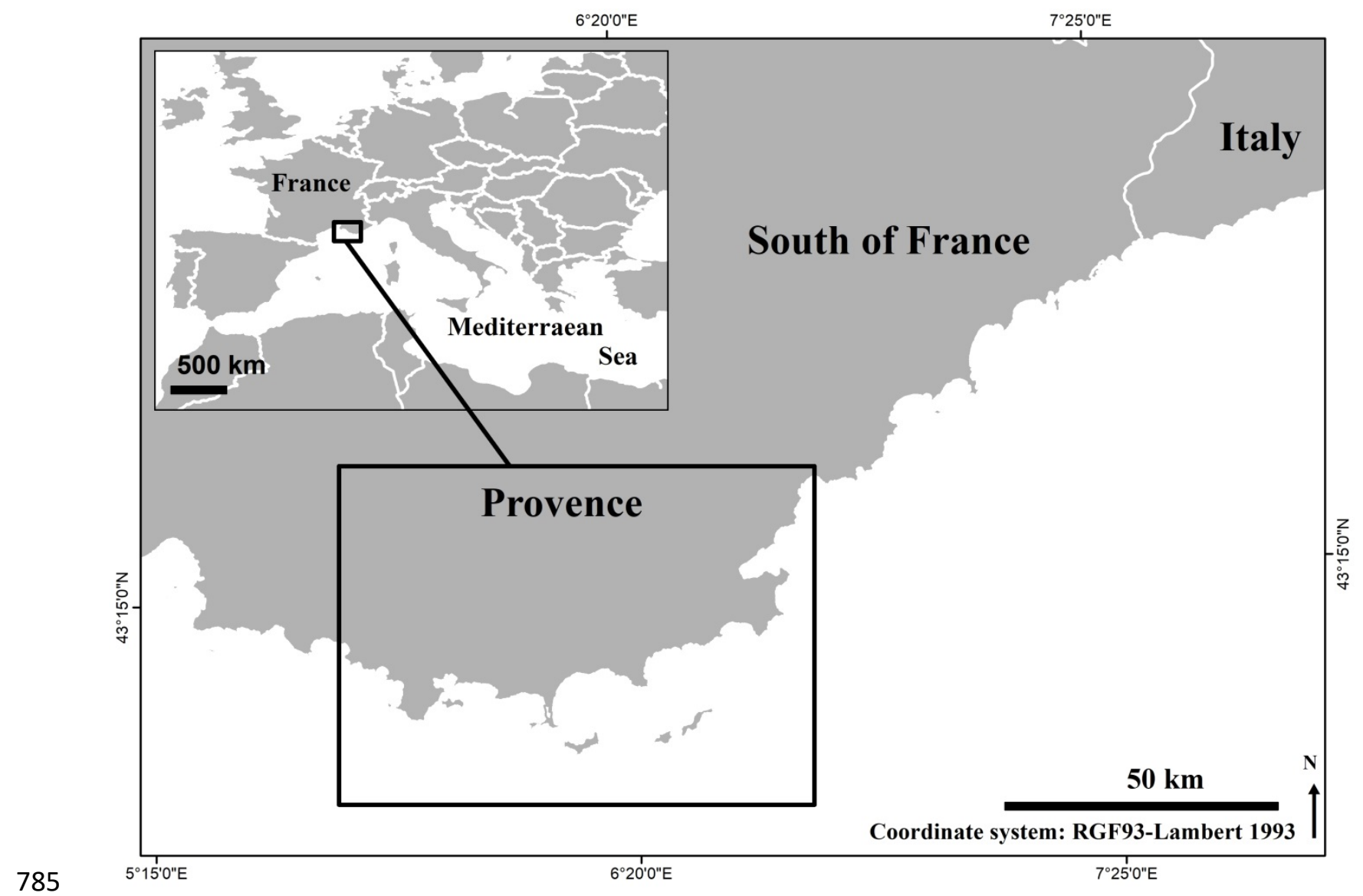

786 Figure 1. Map of the studied area: 42 stations were sampled along the $100 \mathrm{~km}$ stretch of the

787 studied portion of the French Riviera coastline (red rectangle) 


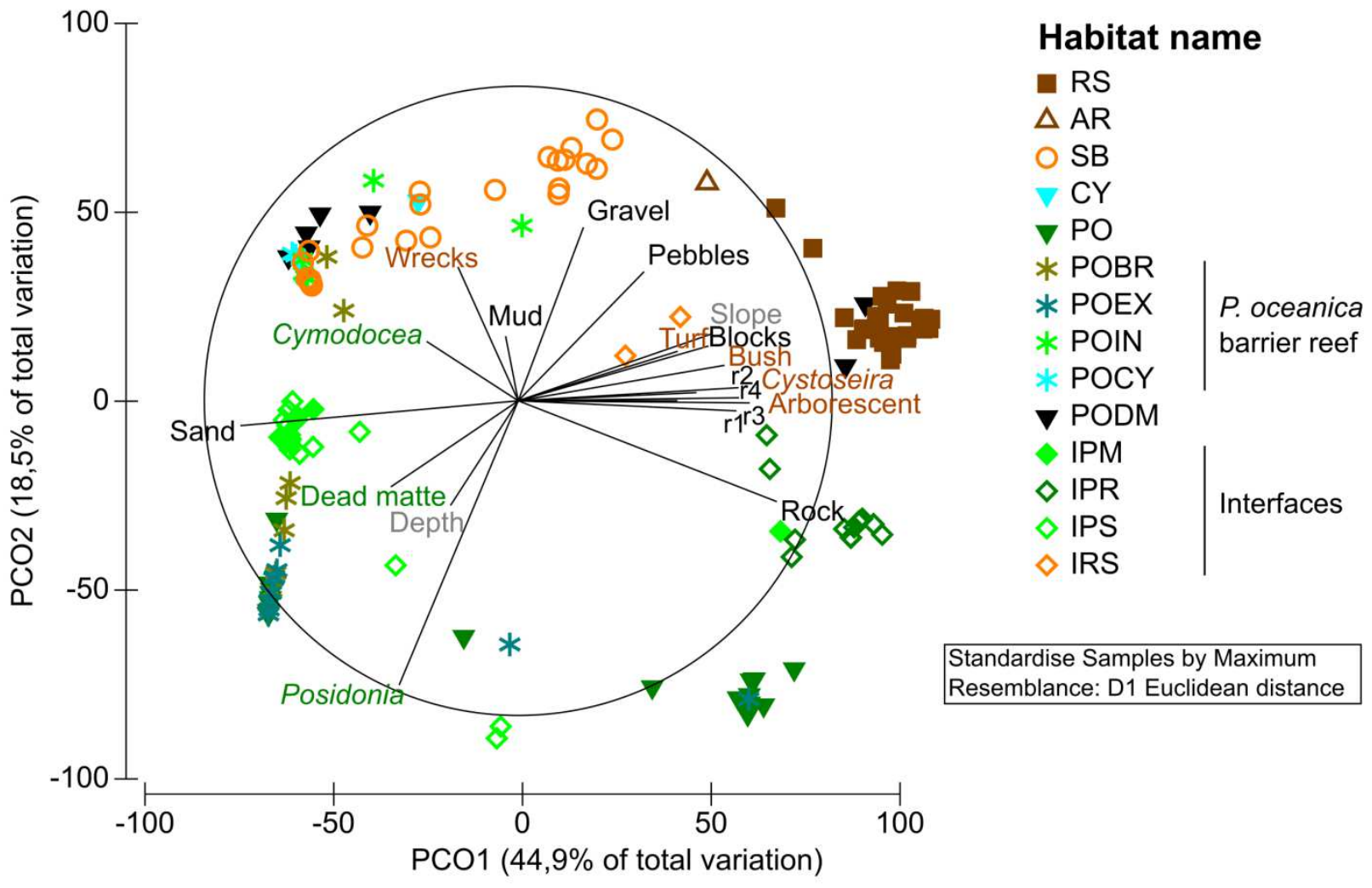

794 Figure 2. Principal coordinate analysis (PCoA) ordination plot of centroids of habitat descriptor 795 assemblages according to habitat types. Correlation vectors (Spearman) of descriptors are plotted 796 (correlations >0.2). RS: Rocky substrates; AR: Artificial rocky reefs; SB: soft bottoms; CY: 797 Cymodocea nodosa beds; PO: Posidonia oceanica beds; POBR: Posidonia barrier reef flat; 798 POEX: Posidonia barrier reef outer slope; POIN: Posidonia barrier reef inner slope; POCY:

799 Barrier reef lagoon with Cymodocea; PODM: Posidonia dead matte; IPR: Interface 800 Posidonia/Rocky substrates; IPS: Interface Posidonia/Soft bottoms; IPM: Interface 801 Posidonia/Dead matte; IRS: Interface Rocky substrates/Soft bottoms. 


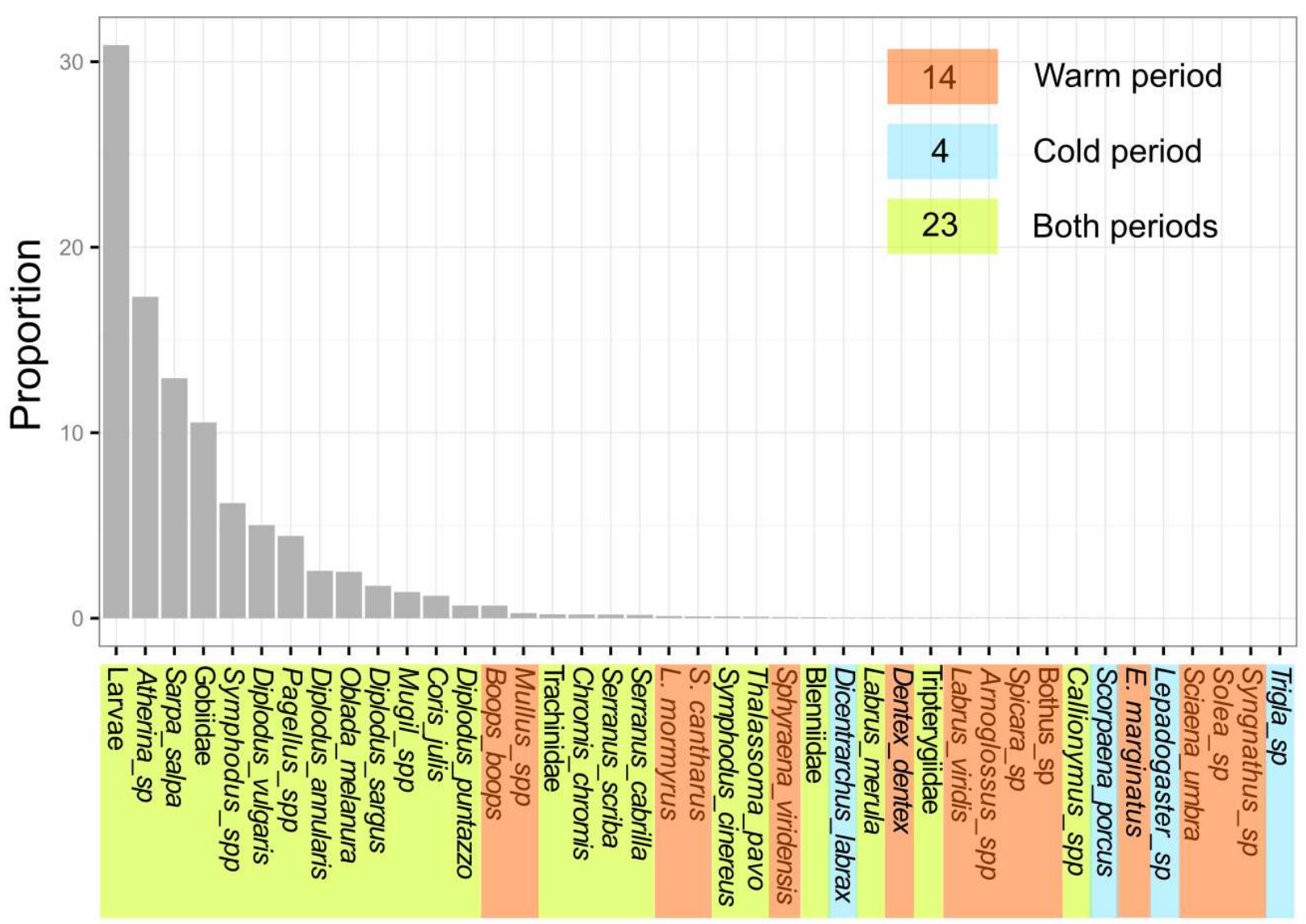

804 Figure 3. Proportion of each observed taxa in the total abundance of juvenile fishes recorded in 805 all samples and habitats combined; E. = Epinephelus, $L .=$ Lithognathus, $S .=$ Spondyliosoma.

806 Period(s) of observation of each taxa and total number of taxa observed per period are indicated 807 with colored boxes.

808 


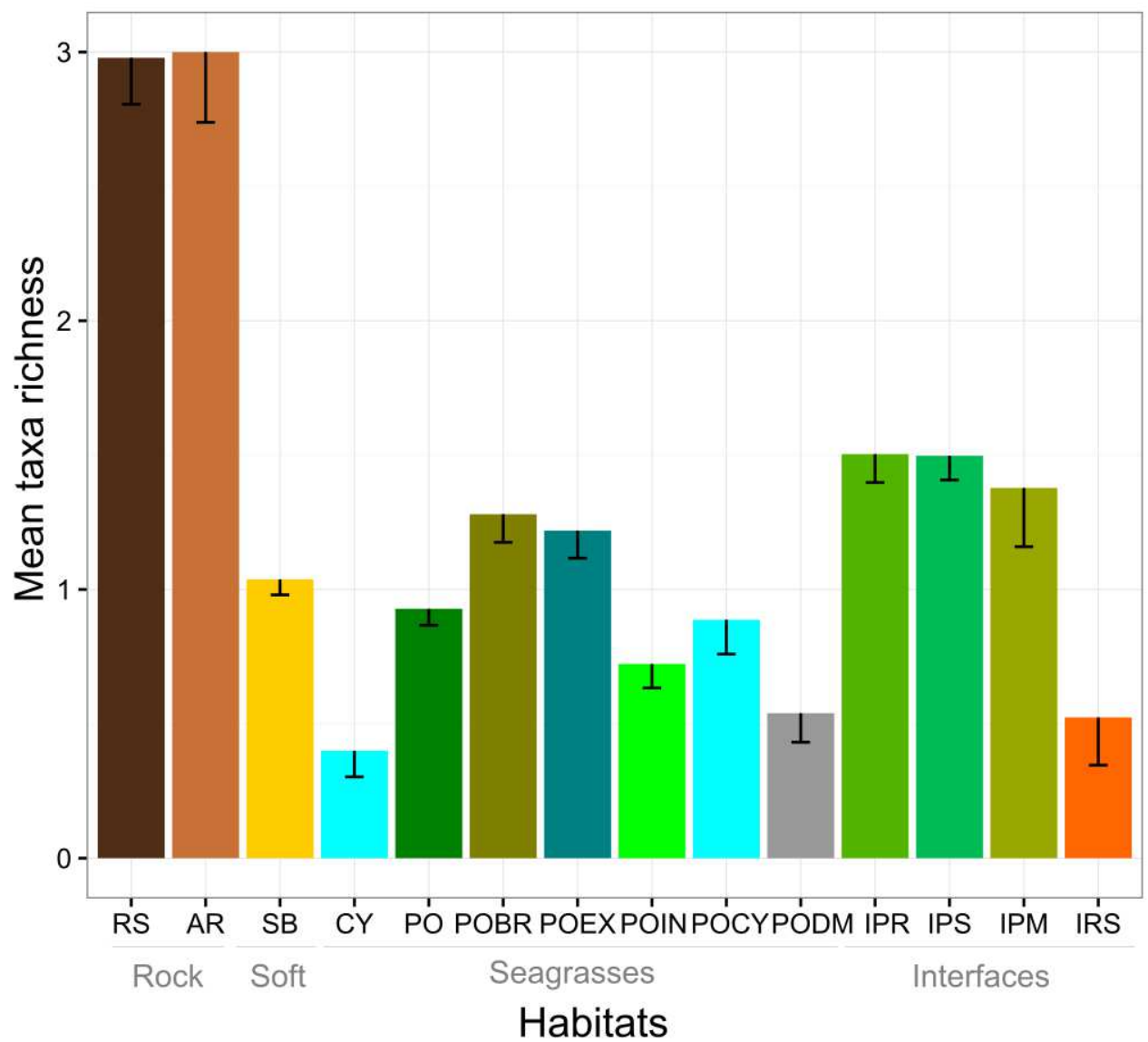

811 Figure 4. Mean taxa richness $\left( \pm \mathrm{SE}\right.$ ) of juvenile fishes per $10 \mathrm{~m}^{2}$ in shallow coastal juvenile

812 habitats. RS: Rocky substrates; AR: Artificial rocky reefs; SB: soft bottoms; CY: Cymodocea

813 beds; PO: Posidonia oceanica beds; POBR: Posidonia barrier reef flat; POEX: Posidonia barrier

814 reef outer slope; POIN: Posidonia barrier reef inner slope; POCY: Barrier reef lagoon with

815 Cymodocea; PODM: Posidonia dead matte; IPR: Interface Posidonia/Rocky substrates; IPS:

816 Interface Posidonia/Soft bottoms; IPM: Interface Posidonia/Dead matte; IRS: Interface Rocky

817 substrates/Soft bottoms. Main habitat categories are indicated in grey. 


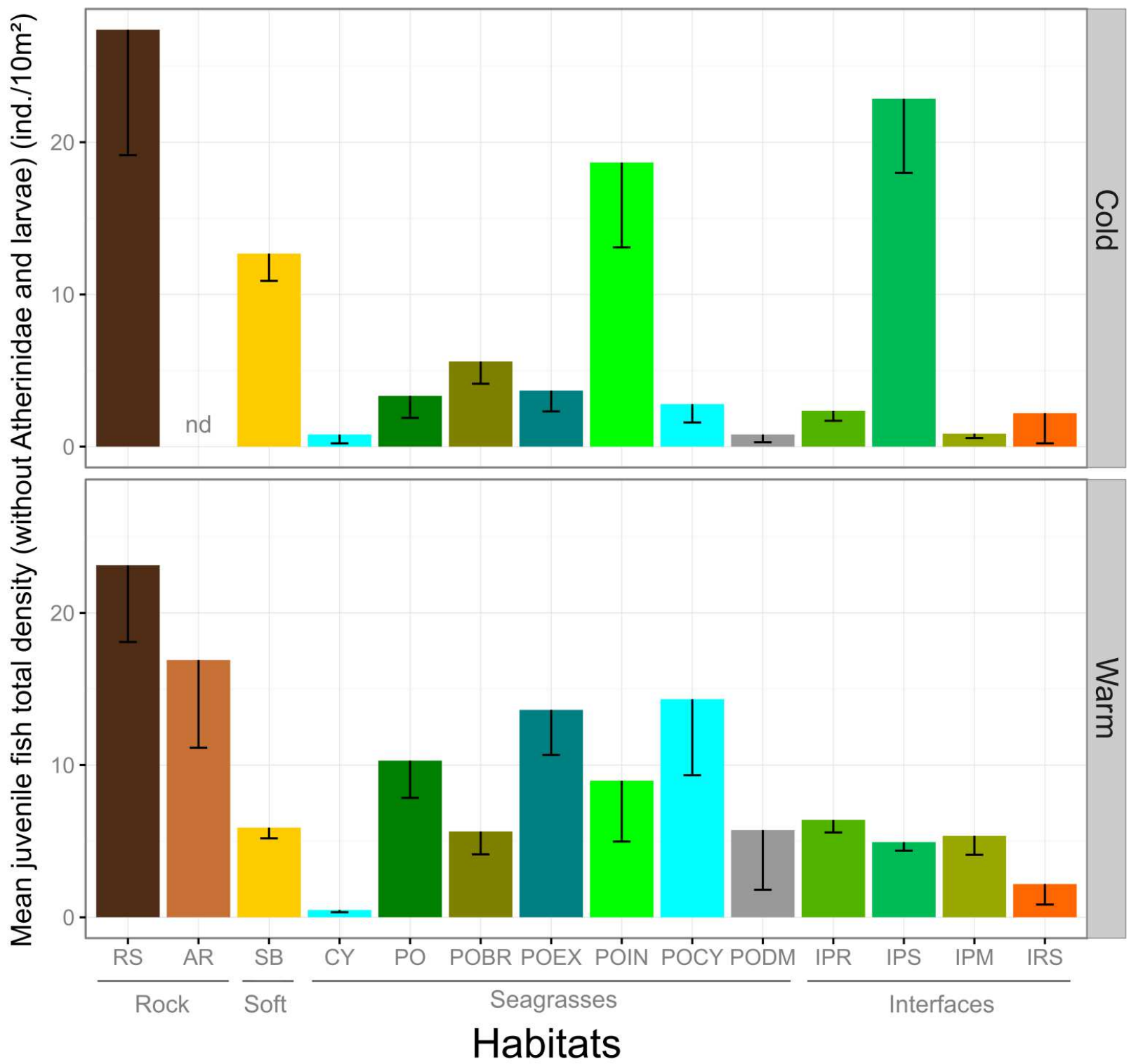

819

820 Figure 5. Mean $( \pm \mathrm{SE})$ total density (without Atherinidae and larvae) of juvenile fishes among

821 habitats for both periods (Cold and Warm). Main habitat categories are indicated in grey; "nd" = 822 no data available.

823

824 


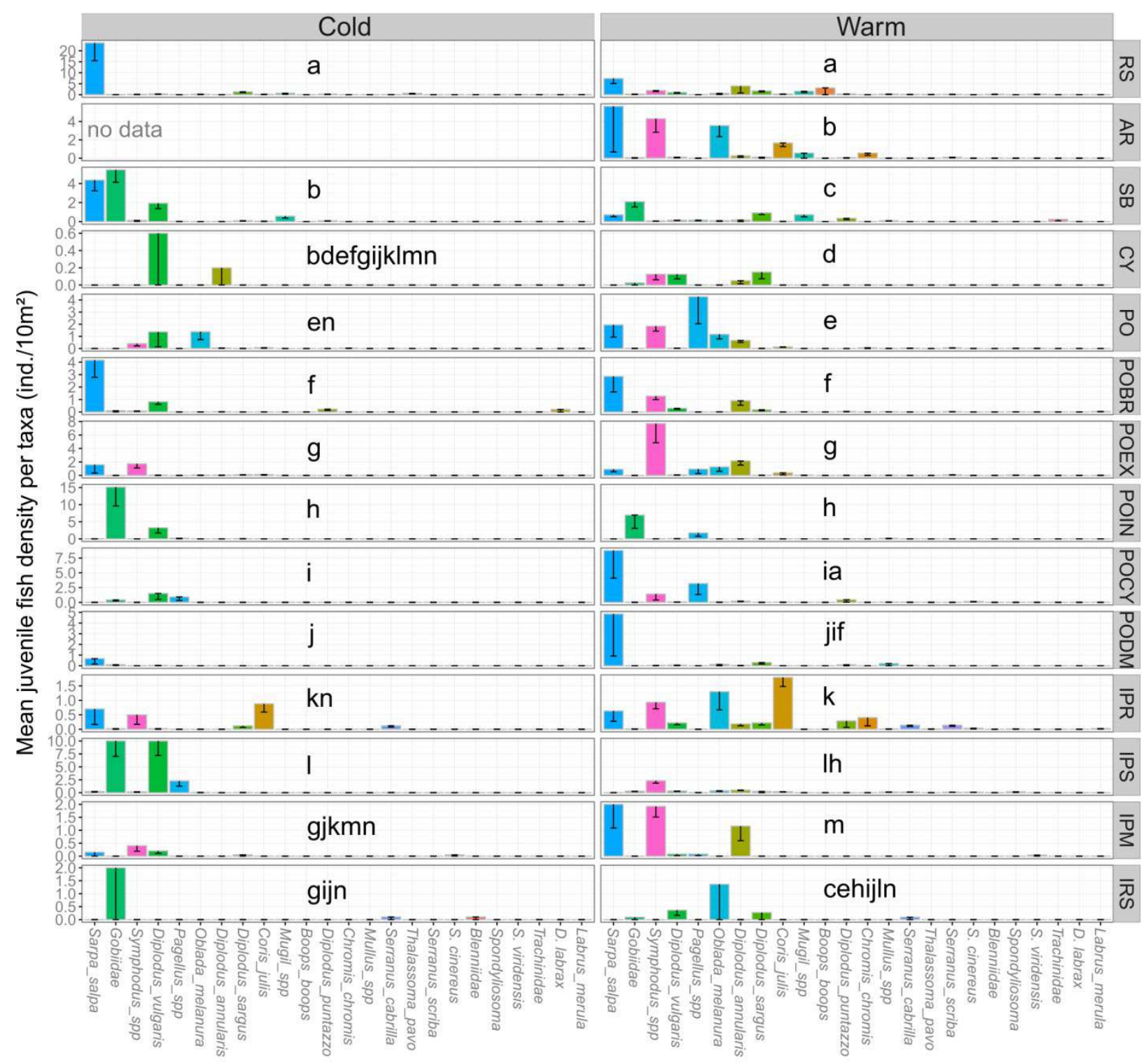

827 Figure 6. Mean ( \pm SE) juvenile density of each taxa in juvenile habitats for both periods (Cold 828 and Warm). Atherinidae and larvae, as well as the 15 least abundant taxa, were removed for a 829 clearer representation. Note that vertical axes display different scales. S. cinereus $=$ Symphodus 830 cinereus $;$ S. viridensis $=$ Sphyraena viridensis $;$ D. labrax = Dicentrarchus labrax ; Details of taxa 831 are given in Table S2. For each period, comparisons of juvenile fish assemblages between 832 juvenile habitats (pairwise tests results) are given (treatments that share at least one lower case 833 character do not significantly differ). 


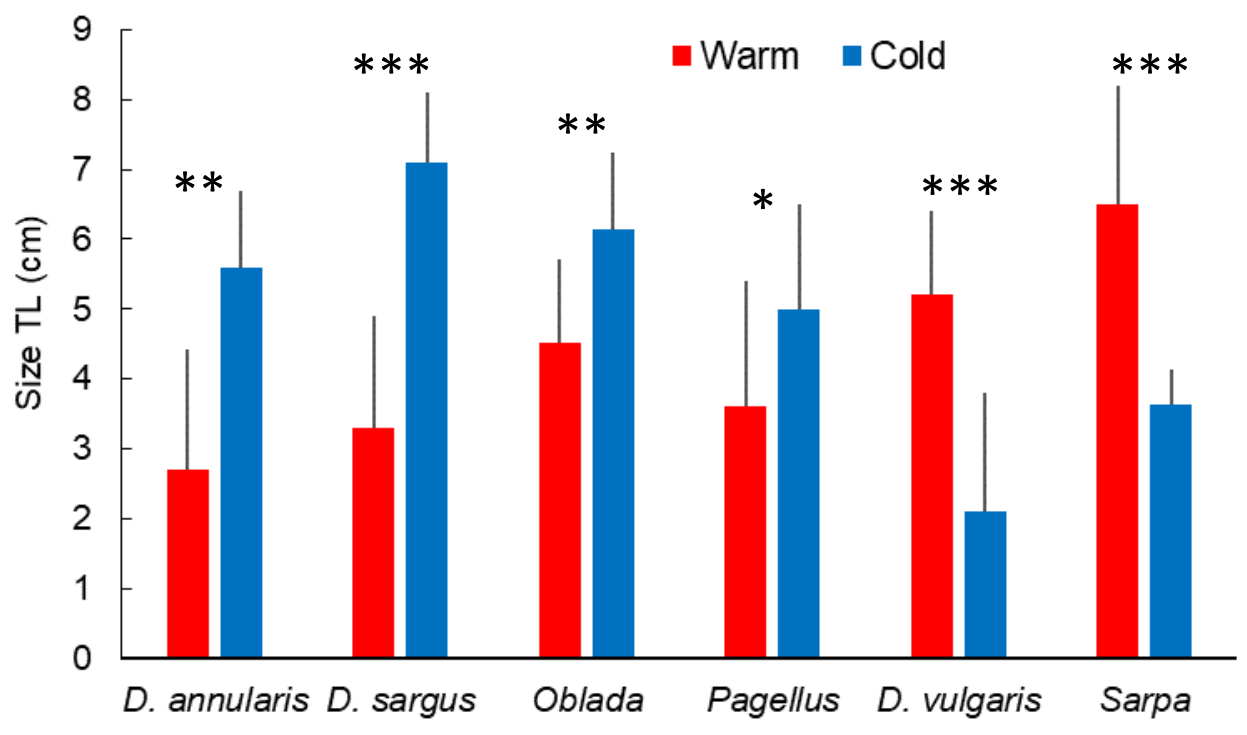

848

849

850 Figure 7. Mean size (TL cm $\pm \mathrm{SD}$ ) of some fish species juveniles settling in Mediterranean

851 shallow coastal habitats. D. = Diplodus; Oblada= Oblada melanura; Pagellus = Pagellus spp.;

852 Sarpa = Sarpa salpa. Warm: warm period (summer 2014); Cold: cold period (winter 2015).

853 Results of t-test for difference in mean size of a given species according to period: $*=p<0.05$;

$854 * * * \mathrm{p}<0.01 ; * * *=\mathrm{p}<0.001$.

855 
858 Table 1. Habitat types, codes and number of samples (N) in warm (summer 2014) and cold 859 (winter 2015) periods.

860

\begin{tabular}{lccc}
\hline Habitat type & Code & Warm period & Cold period \\
& & N & N \\
\hline Rocky substrates & RS & 328 & 150 \\
Artificial rocky reefs & AR & 20 & 0 \\
Soft bottoms & SB & 271 & 155 \\
Cymodocea nodosa beds & CY & 40 & 5 \\
Posidonia oceanica beds & PO & 174 & 90 \\
Posidonia barrier reef flat & POBR & 75 & 50 \\
Posidonia barrier reef outer slope & POEX & 64 & 50 \\
Posidonia barrier reef inner slope & POIN & 71 & 30 \\
Barrier reef lagoon with Cymodocea & POCY & 51 & 20 \\
Posidonia dead matte & PODM & 33 & 30 \\
Interface Posidonia/Rocky substrata & IPR & 87 & 50 \\
Interface Posidonia/Soft bottoms & IPS & 126 & 65 \\
Interface Posidonia/Dead matte & IPM & 25 & 20 \\
Interface Rocky substrates/Soft bottoms & IRS & 11 & 10 \\
\hline TOTAL & & 1376 & 725 \\
\hline
\end{tabular}


Table 2. Abiotic and biotic habitat descriptors of shallow coastal nurseries.

\begin{tabular}{|c|c|c|}
\hline Descriptor & Type & Units, scales or levels \\
\hline Depth & Continuous & Meters \\
\hline Slope (Integer scale) & $\begin{array}{l}\text { Numerical } \\
\text { scale of } \\
\text { integers } \\
\text { from } 1 \text { to } \\
6:\end{array}$ & $\begin{array}{l}1\left(0-15^{\circ}\right) ; 2\left(16-30^{\circ}\right) ; 3\left(31-60^{\circ}\right) ; 4\left(61-<90^{\circ}\right) ; 5\left(90^{\circ}\right) ; 6 \\
\left(>90^{\circ}\right)\end{array}$ \\
\hline Substrate (6 types) & $\begin{array}{l}\% \text { cover } \\
\text { for each of } \\
6 \text { types }\end{array}$ & Rock, blocks, pebbles, gravel, sand, mud \\
\hline Rugosity (4 types) & $\begin{array}{c}\% \text { cover of } \\
\text { each of } 4 \\
\text { types }\end{array}$ & Low, medium, high, very high \\
\hline $\begin{array}{l}\text { Vegetal coverage: } \\
\text { Seagrasses ( } 3 \text { types) }\end{array}$ & $\begin{array}{l}\% \text { cover } \\
\text { for each of } \\
3 \text { types }\end{array}$ & Posidonia oceanica, dead matte, Cymodocea nodosa \\
\hline $\begin{array}{l}\text { Vegetal coverage: } \\
\text { Macrophytes ( } 5 \text { types) }\end{array}$ & $\begin{array}{l}\% \text { cover } \\
\text { for each of } \\
5 \text { types }\end{array}$ & $\begin{array}{l}\text { - Cystoseira sensus lato forest (Carpodesmia brachycarpa, } \\
\text { Carpodesmia crinita, Treptacantha barbata, Cystoseira } \\
\text { compressa) } \\
\text { - Other arborescent algae (Halopitys incurva, Spaerococcus } \\
\text { coronopifolius) } \\
\text { - Bushland (Halopteris scoparia, Padina sp., Dictyotales, } \\
\text { Corallina sp., Acetabularia acetabulum, Laurencia spp.) } \\
\text { - Turf/encrusting algae } \\
\text { - Wrecked algae }\end{array}$ \\
\hline Canopy height & Continuous & $\begin{array}{l}\text { Height }(\mathrm{cm}) \text { of canopy (only for each seagrass or } \\
\text { macrophytes types) }\end{array}$ \\
\hline
\end{tabular}


Table 3. PERMANOVA table of results: comparison of habitat descriptors assemblage per

871 station between habitats and period. Table gives degrees of freedom (df), Mean Squares (MS),

872 calculated pseudo-F, and P-values (P). P-values were obtained by 999 permutations of residuals 873 under a reduced model (perm) or through Monte Carlo test (MC, see methods).

874

\begin{tabular}{lcccc}
\hline Source of variation & df & MS & Pseudo-F & P(perm) \\
\hline Habitat type $(\mathrm{Ha})$ & 13 & 72942 & 18.367 & 0.001 \\
Period (Pe) & 1 & 3352.3 & 0.84415 & 0.502 \\
Ha x Pe & 12 & 3889 & 0.9793 & 0.518 \\
Residuals & 130 & 3971.2 & & \\
Total & 156 & & & \\
\hline
\end{tabular}

875

876

877

878

879

880

Table 4. Total number of fish taxa recorded in the different juvenile habitats of shallow coastal

881 areas, and during the warm (summer 2014) and cold (winter 2015) periods.

882

\begin{tabular}{cccc}
\hline Habitat type & Total & Warm period & Cold period \\
\hline RS & 22 & 22 & 15 \\
AR & 14 & 14 & - \\
SB & 25 & 22 & 15 \\
CY & 6 & 6 & 2 \\
PO & 22 & 21 & 10 \\
POBR & 15 & 14 & 8 \\
POEX & 16 & 15 & 9 \\
POIN & 14 & 13 & 6 \\
POCY & 16 & 15 & 3 \\
PODM & 12 & 10 & 4 \\
IPR & 21 & 20 & 8 \\
IPS & 21 & 21 & 12 \\
IPM & 11 & 8 & 6 \\
IRS & 8 & 7 & 3 \\
\hline TOTAL & 41 & 37 & 27 \\
\hline
\end{tabular}


Table 5. PERMANOVA table of results: comparison of taxa richness of juvenile assemblages between habitats and periods. Table gives degrees of freedom (df), Mean Squares (MS), calculated pseudo-F, and P-values (P). P-values were obtained by 999 permutations of residuals under a reduced

891 model (perm) or through Monte Carlo test (MC, see methods).

\begin{tabular}{lcccc}
\hline Source & df & MS & Pseudo-F & P(perm) \\
\hline $\mathrm{Ha}$ & 13 & 28,253 & 22,632 & 0,001 \\
$\mathrm{Pe}$ & 1 & 53,082 & 42,52 & 0,001 \\
$\mathrm{HaxPe}$ & 12 & 7,4477 & 5,9658 & 0,001 \\
Res & 1689 & 1,2484 & & \\
Total & 1715 & & & \\
\hline
\end{tabular}

Table 6. PERMANOVA table of results: comparison of total juvenile density between habitats and periods. Table gives degrees of freedom (df), Mean Squares (MS), calculated pseudo-F, and P-values (P). P-values were obtained by 999 permutations of residuals under a reduced model (perm) or through Monte 900 Carlo test (MC, see methods). Atherinidae and larvae have been removed for a clearer representation.

\begin{tabular}{lcccc}
\hline Source & df & MS & Pseudo-F & P(perm) \\
\hline Ha & 13 & 3002,7 & 6,0563 & 0,001 \\
Pe & 1 & 9,7155 & 0,019596 & 0,878 \\
HaxPe & 12 & 2364,2 & 4,7686 & 0,001 \\
Res & 1689 & 495,79 & & \\
Total & 1715 & & & \\
\hline
\end{tabular}

Table 7. PERMANOVA table of results: comparison of multivariate assemblage of juvenile density between habitats and periods. Table gives degrees of freedom (df), Mean Squares (MS), calculated pseudo-F, and P-values (P). P-values were obtained by 999 permutations of residuals under a reduced model (perm) or through Monte Carlo test (MC, see methods).

909

\begin{tabular}{lcccc}
\hline Source & df & MS & Pseudo-F & P(perm) \\
\hline $\mathrm{Ha}$ & 13 & 17,591 & 10,738 & 0,001 \\
$\mathrm{Pe}$ & 1 & 19,628 & 11,982 & 0,001 \\
HaxPe & 12 & 7,8712 & 4,8049 & 0,001 \\
Res & 1689 & 1,6382 & & \\
Total & 1715 & & & \\
\hline
\end{tabular}


Figures

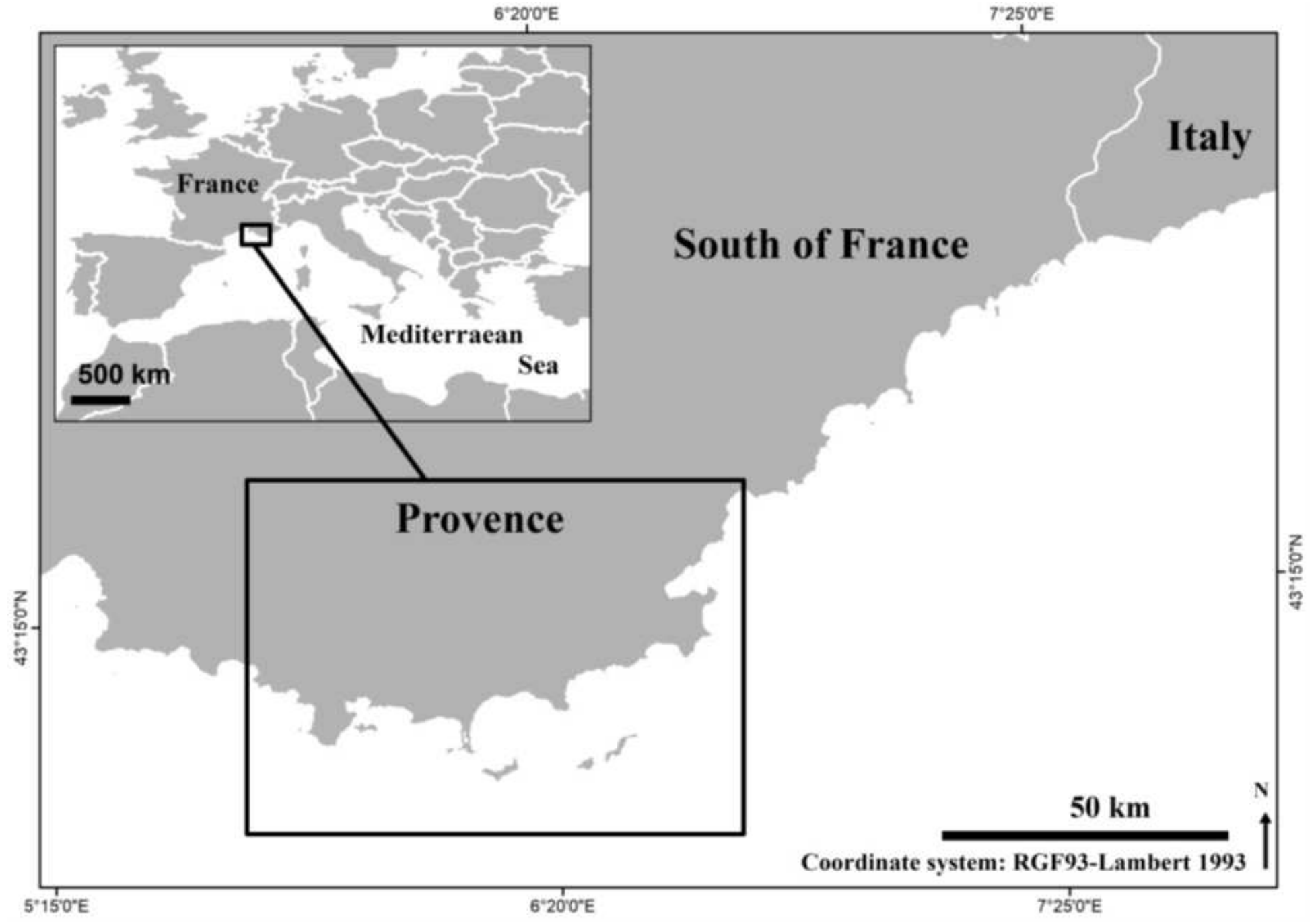

\section{Figure 1}

Map of the studied area: 42 stations were sampled along the $100 \mathrm{~km}$ stretch of the studied portion of the French Riviera coastline (red rectangle) 


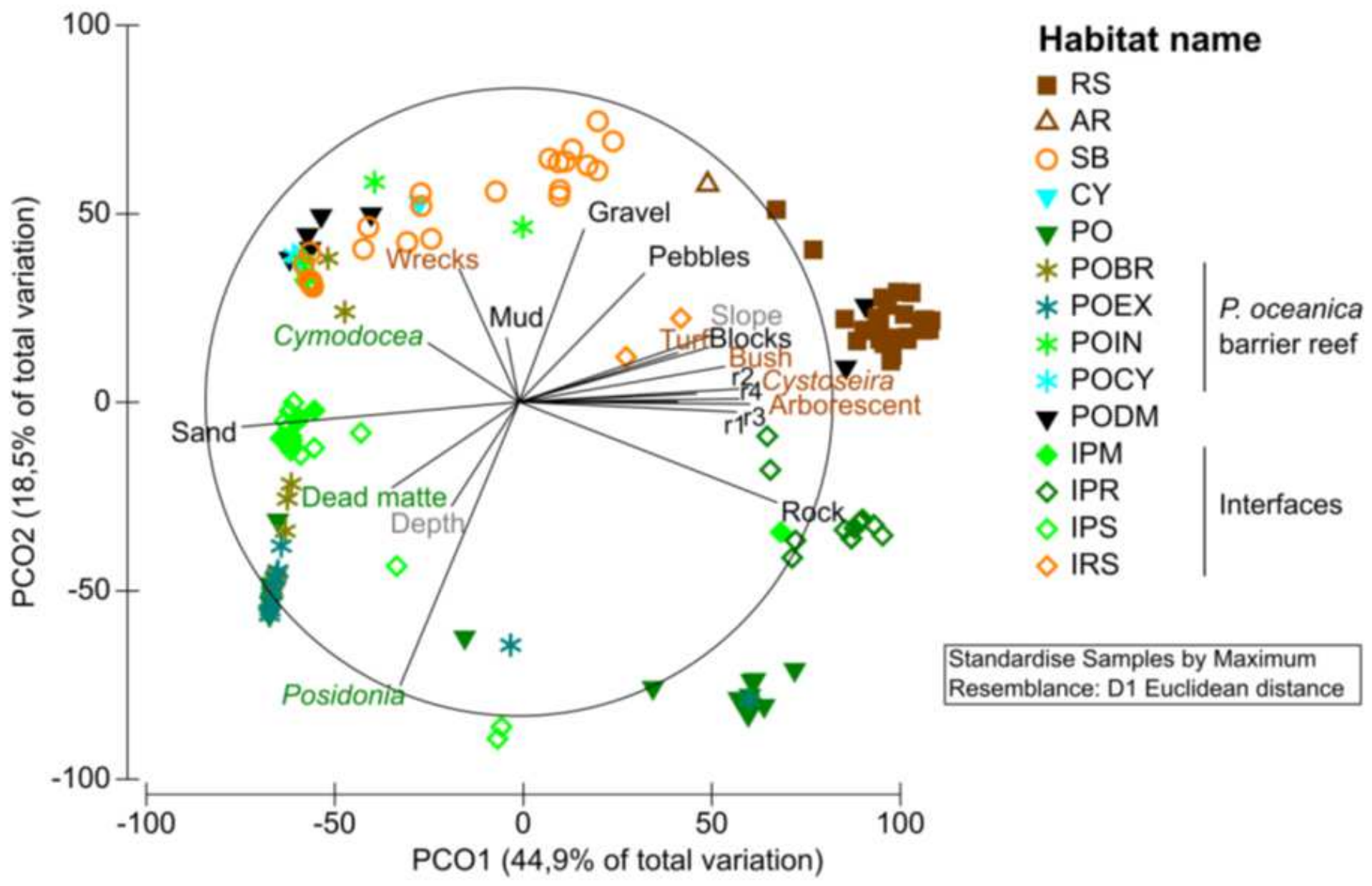

Figure 2

Principal coordinate analysis (PCOA) ordination plot of centroids of habitat descriptor assemblages according to habitat types. Correlation vectors (Spearman) of descriptors are plotted (correlations $>0.2$ ). RS: Rocky substrates; AR: Artificial rocky reefs; SB: soft bottoms; CY: Cymodocea nodosa beds; PO: Posidonia oceanica beds; POBR: Posidonia barrier reef flat;POEX: Posidonia barrier reef outer slope; POIN: Posidonia barrier reef inner slope; POCY:Barrier reef lagoon with Cymodocea; PODM: Posidonia dead matte; IPR: Interface Posidonia/Rocky substrates; IPS: Interface Posidonia/Soft bottoms; IPM: Interface Posidonia/Dead matte; IRS: Interface Rocky substrates/Soft bottoms. 


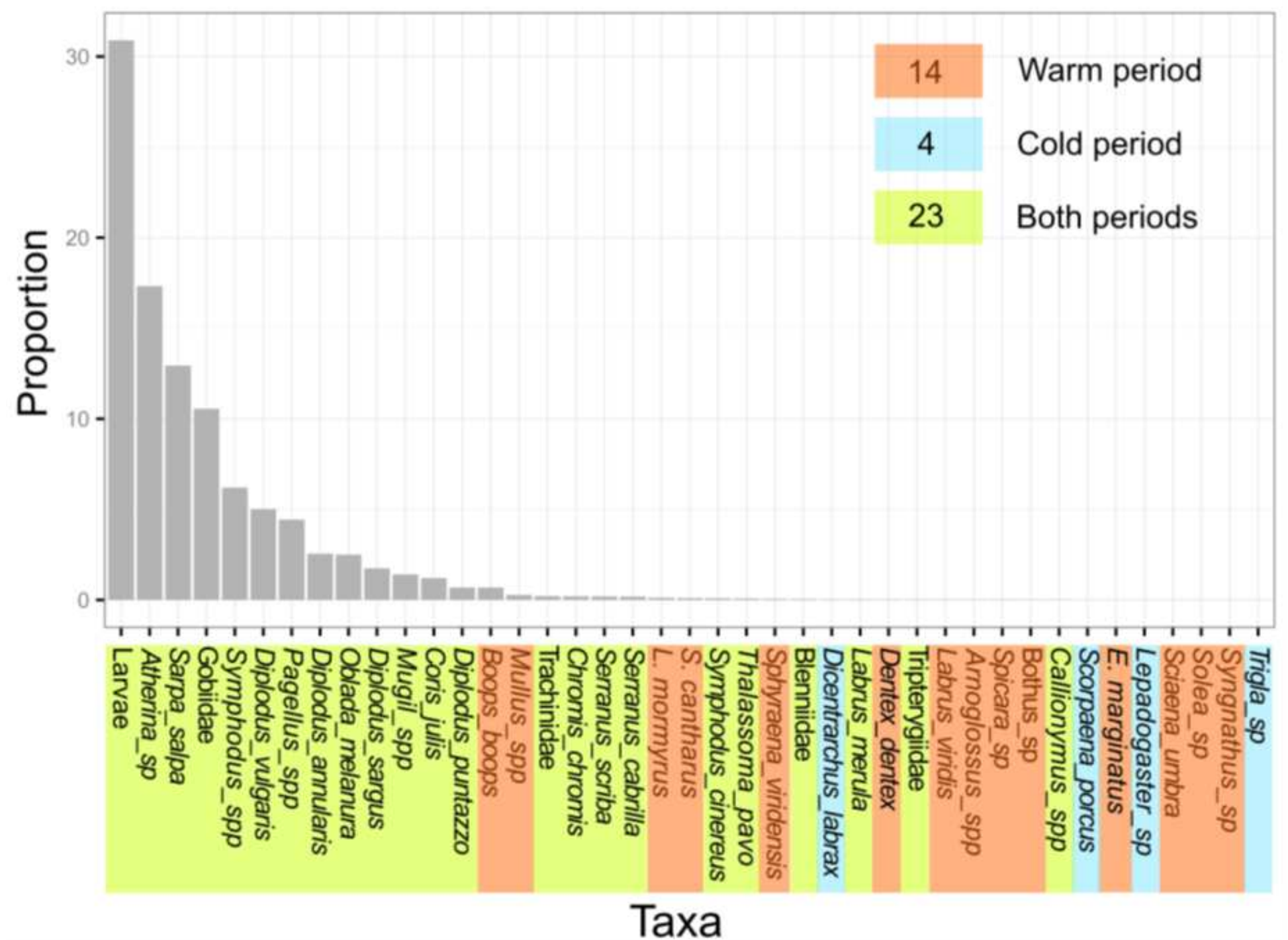

Figure 3

Proportion of each observed taxa in the total abundance of juvenile fishes recorded in all samples and habitats combined; E. = Epinephelus, L. = Lithognathus, S. = Spondyliosoma. Period(s) of observation of each taxa and total number of taxa observed per period are indicated 806 with colored boxes. 


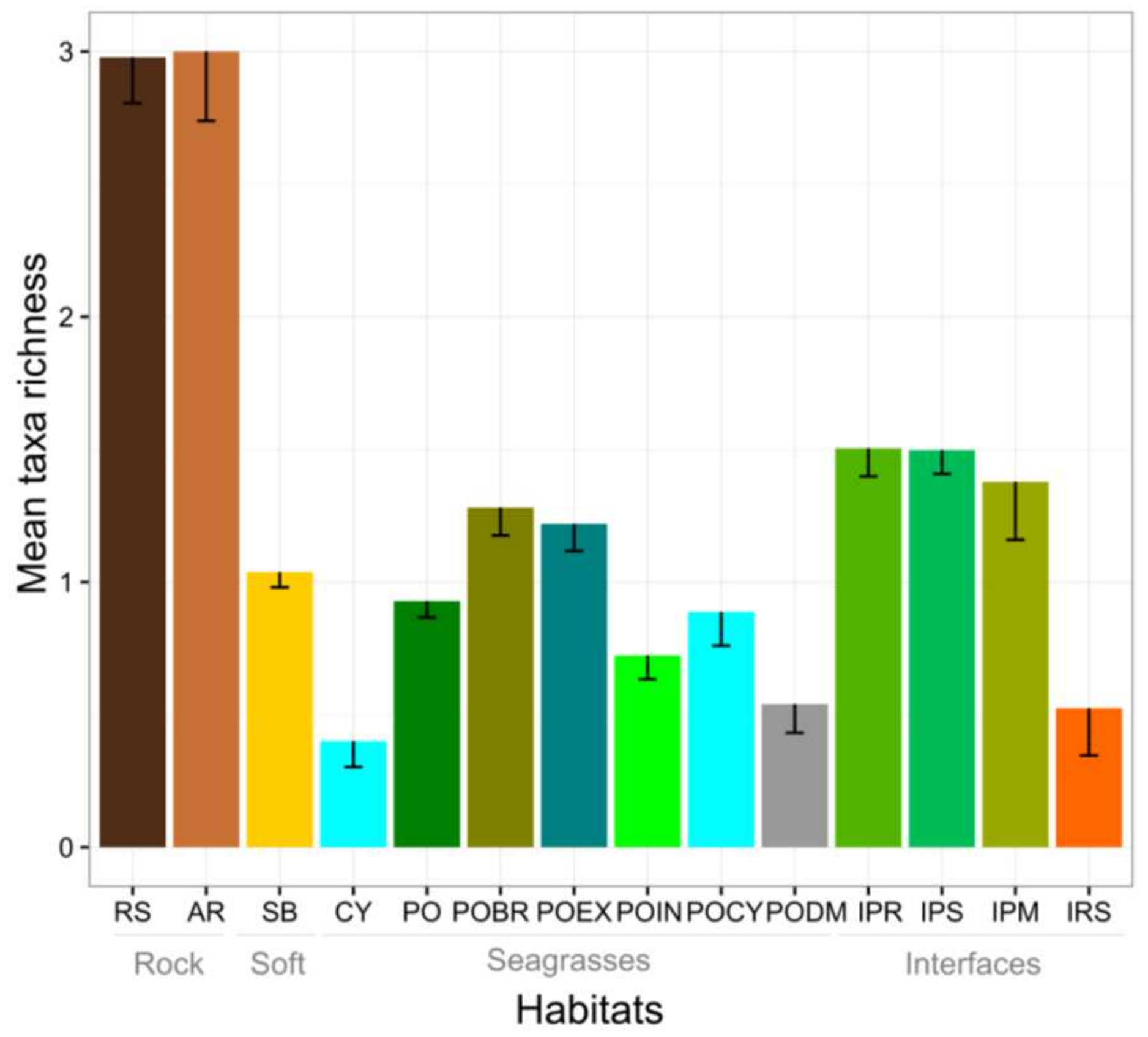

\section{Figure 4}

Mean taxa richness ( \pm SE) of juvenile fishes per $10 \mathrm{~m} 2$ in shallow coastal juvenile habitats. RS: Rocky substrates; AR: Artificial rocky reefs; SB: soft bottoms; CY: Cymodocea beds; PO: Posidonia oceanica beds; POBR: Posidonia barrier reef flat; POEX: Posidonia barrier reef outer slope; POIN: Posidonia barrier reef inner slope; POCY: Barrier reef lagoon with Cymodocea; PODM: Posidonia dead matte; IPR: Interface Posidonia/Rocky substrates; IPS: Interface Posidonia/Soft bottoms; IPM: Interface Posidonia/Dead matte; IRS: Interface Rocky substrates/Soft bottoms. Main habitat categories are indicated in grey. 


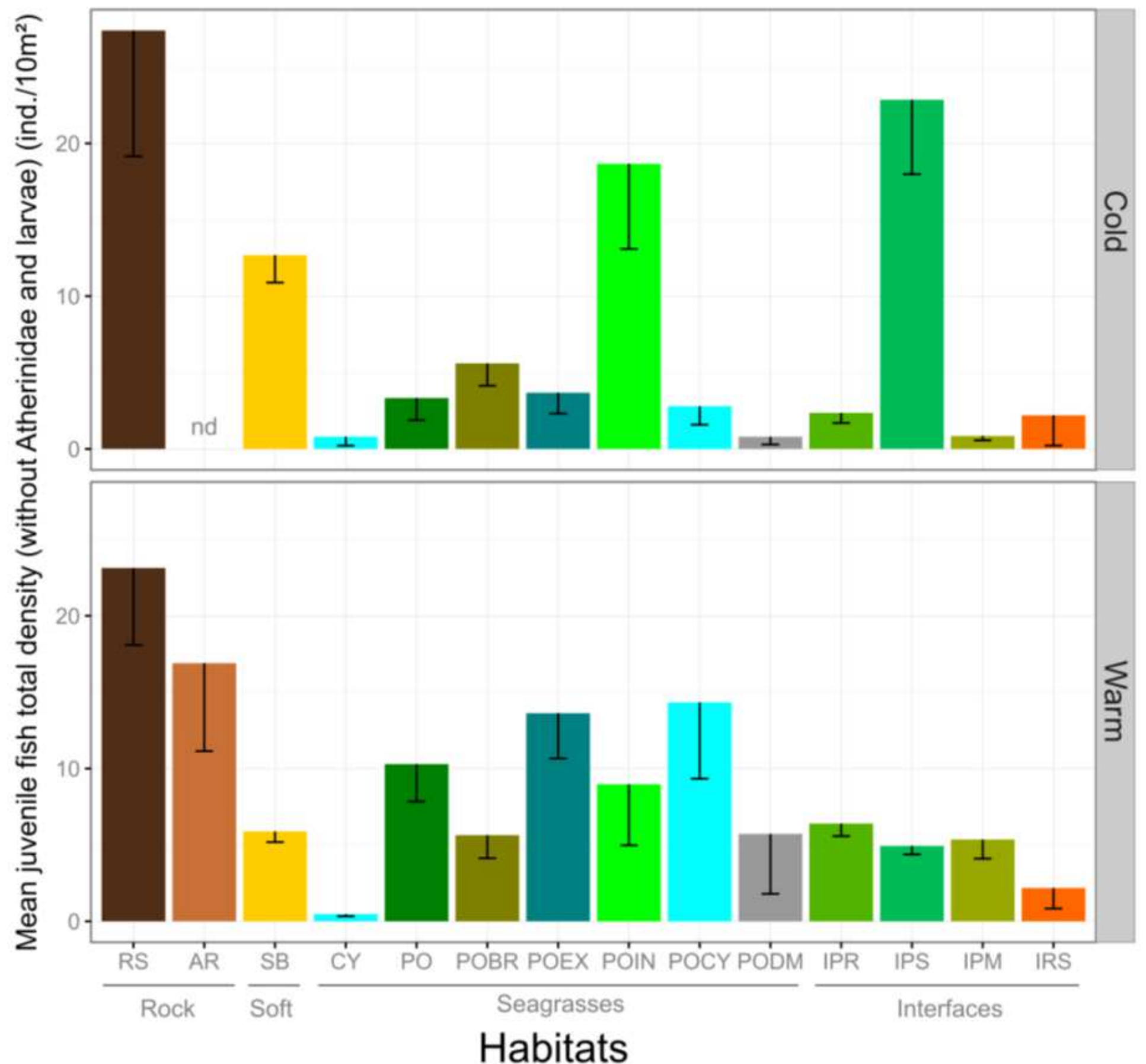

Figure 5

Mean ( \pm SE) total density (without Atherinidae and larvae) of juvenile fishes among habitats for both periods (Cold and Warm). Main habitat categories are indicated in grey; "nd" = no data available. 


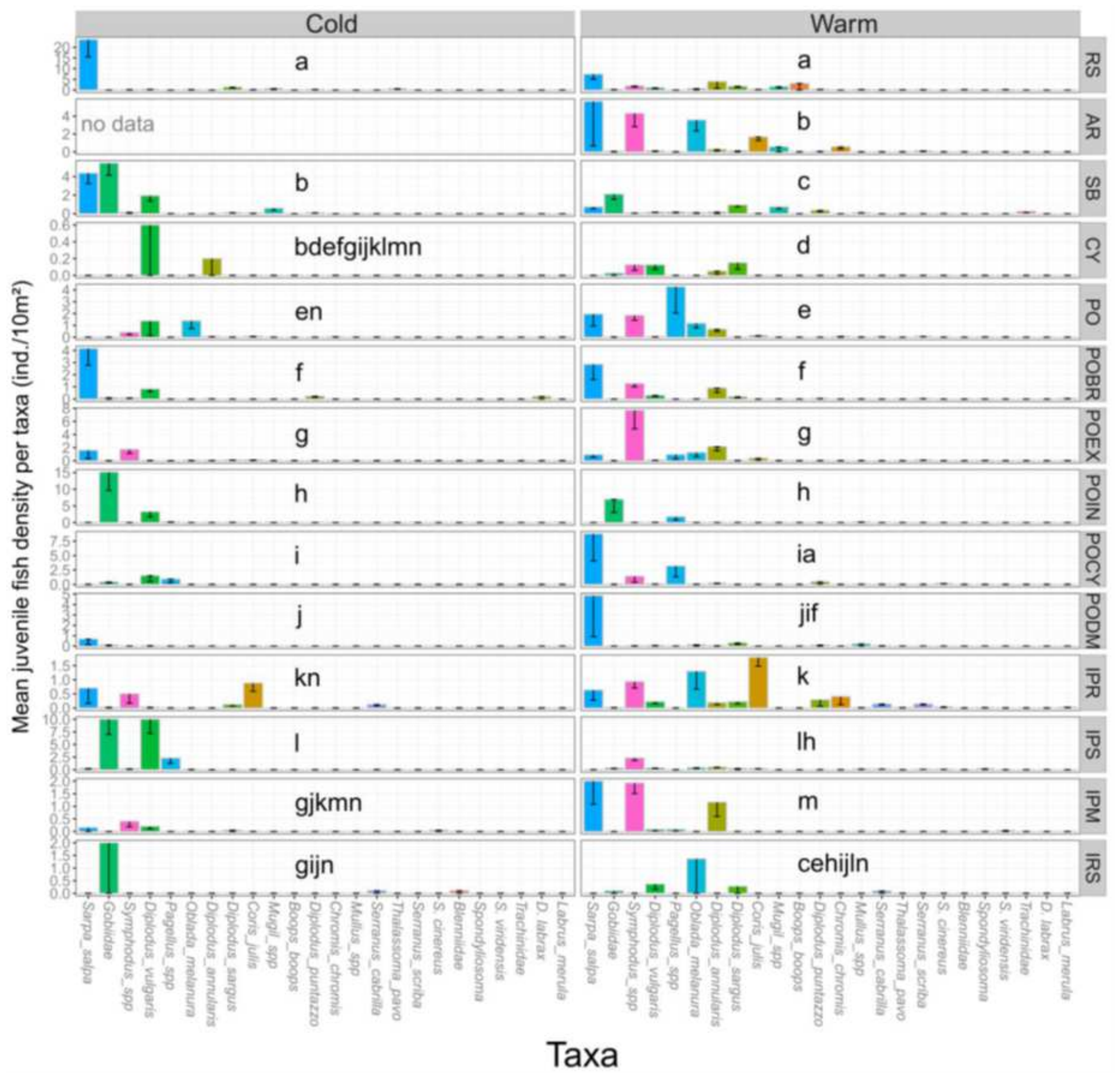

\section{Figure 6}

Mean ( \pm SE) juvenile density of each taxa in juvenile habitats for both periods (Cold and Warm). Atherinidae and larvae, as well as the 15 least abundant taxa, were removed for a clearer representation. Note that vertical axes display different scales. S. cinereus = Symphodus cinereus; $\mathbf{S}$. viridensis = Sphyraena viridensis; D. labrax = Dicentrarchus labrax; Details of taxaare given in Table S2. For each period, comparisons of juvenile fish assemblages between juvenile habitats (pairwise tests results) are given (treatments that share at least one lower case character do not significantly differ). 


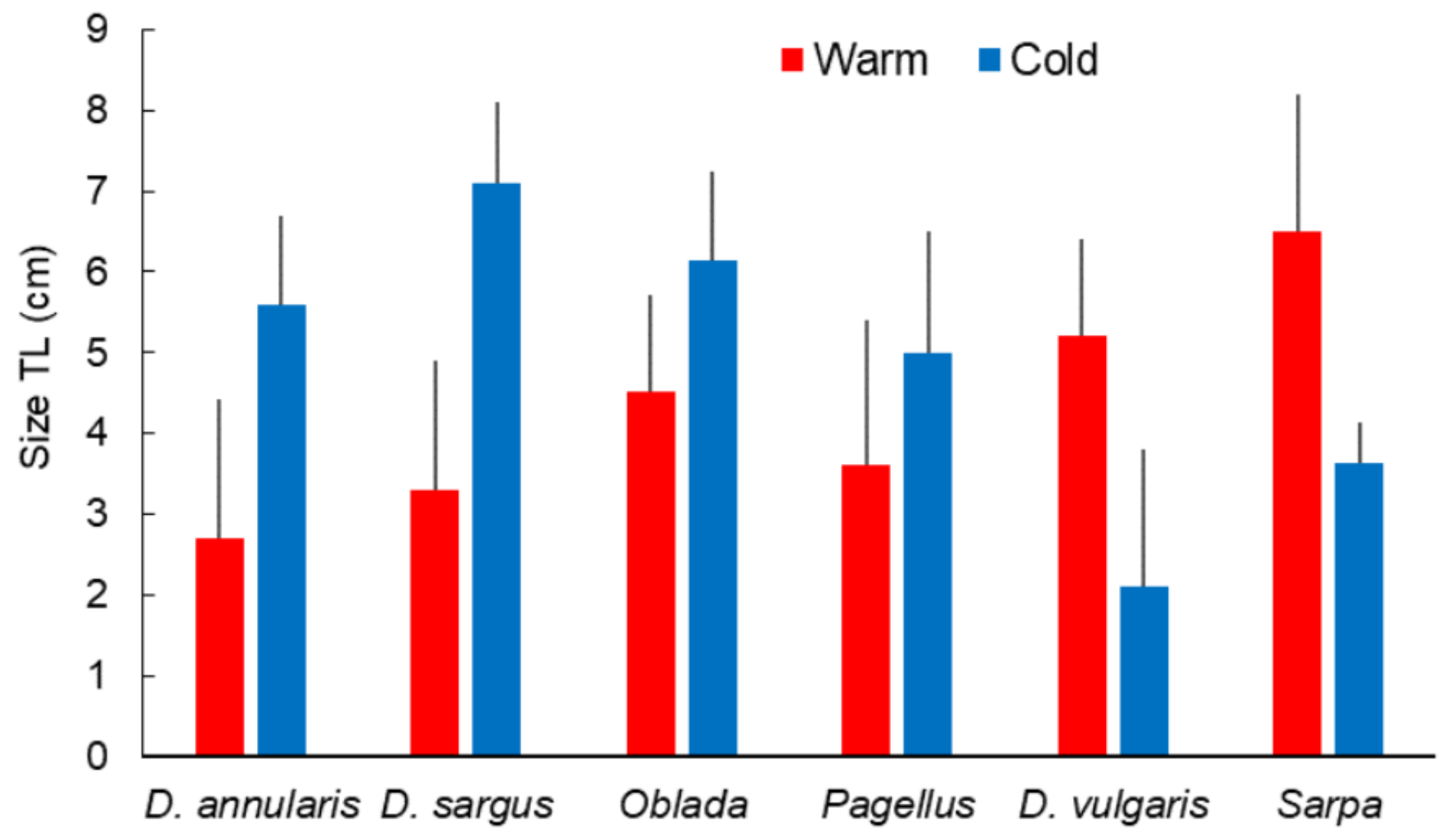

Figure 7

Mean size $(T L \mathrm{~cm} \pm \mathrm{SD})$ of some fish species juveniles settling in Mediterranean shallow coastal habitats. D. = Diplodus; Oblada = Oblada melanura; Pagellus = Pagellus spp.; Sarpa $=$ Sarpa salpa . Warm: warm period (summer 2014); Cold: cold period (winter 2015). Results of t-test for difference in mean size of a given species according to period: $*=p<0.05 ; 853 * \star=p<0.01 ; * \star \star * p<0.001$.

\section{Supplementary Files}

This is a list of supplementary files associated with this preprint. Click to download.

- ChemineeetalSuppTablessubmission.pdf 